\title{
The development of the concept of uniform convergence in Karl Weierstrass's lectures and publications between 1861 and 1886
}

\author{
Klaus Viertel ${ }^{1}$ \\ Received: 6 October 2020 / Published online: 23 December 2020 \\ (c) The Author(s) 2020
}

\begin{abstract}
The history of uniform convergence is typically focused on the contributions of Cauchy, Seidel, Stokes, and Björling. While the mathematical contributions of these individuals to the concept of uniform convergence have been much discussed, Weierstrass is considered to be the actual inventor of today's concept. This view is often based on his well-known article from 1841. However, Weierstrass's works on a rigorous foundation of analytic and elliptic functions date primarily from his lecture courses at the University of Berlin up to the mid-1880s. For the history of uniform convergence, these lectures open up an independent branch of development that is disconnected from the approaches of the previously mentioned authors; to my knowledge, Weierstraß never explicitly referred to Cauchy's continuity theorem (1821 or 1853 ) or to Seidel's or Stokes's contributions (1847). In the present article, Weierstrass's contributions to the development of uniform convergence will be discussed, mainly based on lecture notes made by Weierstrass's students between 1861 and the mid-1880s. The emphasis is on the notation and the mathematical rigor of the introductions to the concept, leading to the proposal to re-date the famous 1841 article and thus Weierstrass's first introduction of uniform convergence.
\end{abstract}

This article presents a considerably re-worked and updated edition of the studies on the history of uniform convergence in Karl Weierstrass's lectures, published in Viertel (2014).

\section{Communicated by Jesper Lützen.}

Klaus Viertel

kviertel@fh-bielefeld.de

1 Department of Engineering and Mathematics, University of Applied Sciences Bielefeld, Interaktion 1, 33619 Bielefeld, Germany 


\section{Introduction}

For a historical understanding of the development of Weierstrass's notion of uniform convergence, it is necessary to understand the connection of the concept as inserted into a text with its context. This paper will mainly focus on the connection between the (verbal and symbolic) form and the mathematical content. Especially in the nineteenth century, we see the growing role of symbols for explicating the meaning of mathematical concepts - until the definitive symbolic form of mathematical statements is achieved. It is on passing from earlier, more rhetorical forms of text, to more symbolic forms that, for instance, ambiguities in verbal formulations become clarified. An important example of this is the emergence of the absolute sign notation. In the course of his lectures, Weierstraß introduced his concepts of uniform convergence, using three different verbal formulations that can be assigned to different periods of the development of this concept in terms of mathematical rigor and applications (i.e., theorems). Behind some of his introductions of uniformity lay a mathematical condition slightly different from uniform convergence. His introductions of uniformity can be conceptually separated into uniform convergence and the Cauchyan uniformity condition (that is to say a sequence of functions is uniformly Cauchy). Under the given circumstances, this notion is equivalent to uniform convergence, which turned out to become the classical notion of the concept. Below I will generally use the wording "uniform convergence" as a generic term for these two notions.

\section{Did Weierstraß introduce uniform convergence as early as in $1841 ?$}

\subsection{The role of Christoph Gudermann and his formulations of convergence}

After the young Karl Weierstraß abandoned his studies at the University of Bonn, he took on more serious studies of mathematics at the Akademie in Münster in 1839-40, where he became a student of Christoph Gudermann. Weierstraß attended his course on elliptic functions and started to work on his teacher's Theorie der Modular-Functionen, which Gudermann began to publish in Crelle's Journal in 1838. This work - dealing with the convergence of infinite series in the context of Jacobian elliptic functions contains a variety of formulations for different rates of convergence, but these rates of convergence are not introduced or explained. He often used the term rasche Konvergenz (fast convergence, cf. Gudermann 1844, pp. 382, 558). In contrast to this, we find the formulations langsam (slow), gering or schwach (weak), indicating different rates of convergence (e.g., Gudermann 1844, pp. 196, 290). But we do not find any further definitions or specifications of these terms in his work. There is also no indication of a difference between the formulations rasch convergent (converging rapidly) and convergent im hohen Grade (convergent at a high rate). The latter term also occurs in his comparison of mathematical expressions with equally high rates of convergence (Gudermann 1844 , p. 200). Both formulations, as well as their variants ${ }^{1}$, seem to

$\overline{1}$ See Gudermann (1844, pp. 192 $, 196,382,558)$. 
describe rates of convergence in terms of pointwise convergence, however, in a quite intuitive way.

There is one passage that has been used to draw a connection to uniform convergence. Reinhard Bölling (1994) interpreted Gudermann's following statement, which occurs only once and is entirely isolated, as a specific notion of uniform convergence: "It is a remarkable fact that both the infinite products in $\$ 58$ and the series just found have an overall equal rate of convergence." 2 Bölling claimed that the term "overall equal rate of convergence" refers to the notion of uniform convergence, attributing to the quoted statement that the same rate of convergence is meant to hold for all values of the variable. From his perspective, Gudermann seems to ignore the connection to uniform convergence: "As it seems, he did not draw any conclusions from it, let alone he made any sense of the significance of this type of convergence." 3 Consequently, we do not find any definition whatsoever of the said term. Moreover, it is questionable to interpret the history of mathematics backward by stating that Gudermann took no notice of uniform convergence, when no concept of it was introduced at the time.

In his doctoral thesis, Kurt Richter (1976, pp. 135-6) assumes that Gudermann not only referred to the term "overall equal rate of convergence" in his publications, but "probably" also in his lecture courses on Modular-Functionen that Weierstraß attended. According to Richter, Weierstraß only adopted the term im gleichen Grad (at the same rate) from Gudermann, who used it in a very restricted manner. ${ }^{4}$ This means that Weierstraß primarily adopted the wording, but not necessarily a concept of uniform convergence, since there is no known introduction of it in Gudermann's work.

\subsubsection{Reinhold Hoppe as a possible recipient of Christoph Gudermann's formulation}

A reception of Gudermann's formulation Convergenz im gleichen Grade can be attributed to the textbook Lehrbuch der Differentialrechnung und Reihentheorie mit strenger Begründung der Infinitesimalrechnung (1865) by Reinhold Hoppe who studied mathematics at the Universities of Kiel, Greifswald, and Berlin and completed his Habilitation thesis at the University of Berlin in 1853. He could have known Gudermann's Modular-Functionen, since he gave the following explanation for the rate of convergence for infinite series:

If the general terms $u_{k}$ and $v_{k}$ of two infinite series are positive for a sufficiently large number $k$, the following four cases can be distinguished with respect to the

\footnotetext{
2 Gudermann (1844, p. 119 f).: „Es ist ein bemerkenswerther Umstand, daß sowohl die unendlichen Producte im $\$ 58$ als auch die soeben gefundenen Reihen einen im Ganzen gleichen Grad der Convergenz haben [...]“" (author's emphasis).

3 Bölling (1994, p. 60): ,[Er] selbst zieht, wie es scheint, keinerlei Folgerungen daraus, geschweige denn nimmt er auch nur ansatzweise etwas von der Bedeutung dieses Konvergenzverhaltens wahr.“

4 Richter (1976, pp. 135-6): Es ist wahrscheinlich, daß er [Weierstraß] die Bezeichnung [Convergenz im gleichen Grade] als solche von seinem Lehrer Gudermann übernommen hat, der diesen Namen wohl zum erstenmal benutzte, wenn auch in wesentlich eingeschränkter Bedeutung. [...] Es ist sehr wahrscheinlich, daß Gudermann diese Bezeichnung [eine im Ganzen gleichen Grad der Convergenz] auch in der Vorlesung über Modularfunktionen verwendete, die Weierstrass bei ihm gehört hat. Daher liegt die Vermutung nahe, daß Weierstrass diesen Begriff in ähnlichem Sinne verwendete, wenn bei einer vorgegebenen Reihe die Abschätzung für alle $x$ eines bestimmten Intervalles galt“ (remarks by K.V.).
} 
quotient $\frac{v_{\omega}}{u_{\omega}}$ : it can be finite, infinitely small, infinitely large, or neither of these. In the first case, for sufficiently large $k$, e.g., $k \geq m, \frac{v_{k}}{u_{k}}<c$ for some constant $c$ [...]. Therefore, both infinite series converge or diverge simultaneously, and one can say that they converge or diverge [175] with the same rate; or: they converge or diverge equally strong. [...] They have the same rate of convergence, if the ratio of their general terms is finite for an infinitely large number $k .^{5}$

In short, Hoppe's "convergence with same rate" aims at the rate of convergence of an infinite series. Note that he did not explain, whether the condition $\frac{v_{k}}{u_{k}}<c$ should hold for all or for just (in)finitely many numbers $k \geq m$. The absence of a clarification of this matter is very common, and it can also be found in Weierstrass's lectures, as we will see. If Hoppe knew Gudermann's work, he adopted his term im gleichen Grade. However, the different rates of convergence of infinite series had already been considered as early as in the eighteenth century. ${ }^{6}$

\subsection{The revision of Weierstrass's famous article from 1841}

The first occurrence of uniform convergence in Weierstrass's works is often dated to 1841. The corresponding paper Zur Theorie der Potenzreihen was published in Mathematische Werke vol. 1 (1894), but signed as "Münster, im Herbst 1841" (Weierstraß 1841, p. 74). In the introduction and in the notes of the Werke, it is pointed out that "most of the papers" has been revised and "special papers" have also been corrected by the editors and others (Weierstraß 1894, pp. v-vi, p. 356). Unfortunately, the scope of each of these revisions or corrections is not explained. In the case of the 1841 article, neither Alfred Pringsheim, nor Richter nor Bölling doubted that the text published in 1894 is identical with the original text. ${ }^{7}$ A recent example is (Gray 2015), who just speaks of an "early" paper that Weierstraß "wrote in 1841" (pp. 199, 197). I will try to give some strong indications for a later revision regarding the introduction of uniform convergence.

From its first page, the article Zur Theorie der Potenzreihen consistently uses the sign for absolute values, namely a vertical line before and after an algebraic expression. Yet, when one looks into mathematical publications of that time, one will not find a use of this notation. Since the eighteenth century, the practice had been to continue in a rhetorical style, writing something like "the value of ... taken absolutely." Cauchy, in his Cours d'analyse algébrique, practiced a variation of such a rhetorical, sign-less denomination: "valeur numérique de ... “. Enno H. Dirksen, although strongly following Cauchy, progressed to the abbreviated mode, the syncopated form: "v.n.", followed

\footnotetext{
5 Hoppe 1865, p. 174 f.: ,Sind die allgemeinen Glider zweier Reihen $u_{k}$ und $v_{k}$ für hinreichend grosse $k$ positiv, so lassen sich inbetreff des Quotienten $\frac{v_{\omega}}{u_{\omega}}$ folgende vier Fälle unterscheiden: er kann 1) endlich 2) unendlich klein 3) unendlich gross 4) keins von allen sein. Im ersten Falle ist für hinreichend grosse $k$, z.B. für $k \geq m \frac{v_{k}}{u_{k}}<c$ für irgend eine Constante $c[\ldots]$. Beide Reihen convergiren oder divergiren demnach gleichzeitig, und man kann sagen: ihre Convergenz oder Divergenz [175] ist von gleichem Grade; oder: sie convergiren oder divergiren gleich stark. [...] Gleichen Grad der Convergenz haben sie, wenn der Quotient irer allgemeinen Glider für unendlich grossen Index endlich ist.“

6 In his 1777 article, Francis Maseres looks at infinite series that can be obtained by the binomial theorem in terms of slow or "swift" convergence (Maseres 1777, p. 194 f.).

7 Pringsheim (1899, p. 35), Richter (1976, pp. 149, 158-9), Bölling (1994, p. 60) and Bölling (2016, p. 55).
} 
by the algebraic expression in normal brackets. In the lecture notes of Weierstrass's students, the modern notion of absolute value is absent until late in the $1860 \mathrm{~s}^{8}{ }^{8}$ There, Weierstraß himself never used the sign, while attributing it in 1894 to himself as of 1841. Before he began to use the modern absolute value sign, his way of expressing the absolute value was either literally "absoluter Betrag von ..." or "Absolutbeträge von ..." or round brackets, which can be found in Pasch's script from 1865/66 (Fig. 1). ${ }^{9}$ To my knowledge, this notation only appears again in a lecture course on elliptic functions from $1868 / 69^{10}$ before it was replaced by the modern notation in a script from $1870 / 71^{11}$. In the 1880 s, we also find the abbreviation "absol. Betr. von ...".

\section{$\left(\Sigma \varphi \varphi(x)-\varphi_{1}(x)-\cdots-\varphi_{n}(x)\right)<\delta^{+}$}

Fig. 1 Weierstrass's notation for the remainder in connection with a definition of uniform convergence

I am indebted to a private communication from Gert Schubring that the apparently first introduction of that modern sign was made by August Leopold Crelle, in a book of 1823 , but this remained an isolated practice, not adopted at the time by other mathematicians.

Furthermore, the 1841 article contains two major theorems, one of which is the double series theorem for power series with several variables. Here, Weierstraß assumed infinitely many power series to be uniformly convergent by using the term gleichmässig convergent (uniform convergent):

There are infinitely many ordinary power series given in a certain sequence:

$$
F_{0}\left(x_{1}, x_{2}, \ldots x_{\varrho}\right), F_{1}\left(x_{1}, x_{2}, \ldots x_{\varrho}\right), F_{2}\left(x_{1}, x_{2}, \ldots x_{\varrho}\right), \ldots
$$

and we suppose that in a given neighbourhood $G$ of $(0,0, \ldots 0)$ not only every single series in this sequence converges unconditionally and uniformly, but also the sum. If we denote the coefficients of $x_{1}^{v_{1}} x_{2}^{v_{2}} \ldots x_{\varrho}^{v_{\varrho}}$ in $F_{\mu}\left(x_{1}, x_{2}, \ldots x_{\varrho}\right)$ with $A_{v_{1}, v_{2}, \ldots v_{\varrho}}^{(\mu)}$ and let

$$
\sum_{(\mu)} A_{v_{1}, v_{2}, \ldots v_{\varrho}}^{(\mu)}=A_{v_{1}, v_{2}, \ldots v_{\varrho}}
$$

one can proof that $A_{v_{1}, v_{2}}, \ldots v_{\varrho}$ is finite and the equation

\footnotetext{
8 We also find (Nakane 2014, p. 56) adding the absolute value sign to his English translation of parts of $\mathrm{H}$. A. Schwarz's lecture notes of Differentialrechnung (1861) on pp. 6-7. Neither did Weierstraß use this sign, nor did he speak of Absolutbeträge (absolute values) or similar terms.

9 University library Gießen, Nachlass Moritz Pasch, Signatur I, 19: Nachschrift einer Weierstraß-Vorlesung v. Moritz Pasch. Berlin, 1865/66, p. 28.

10 BBAW, Nachlass Schwarz, No. 470, Mitschrift der Vorlesung von K. Weierstraß: Elliptische Funktionen. 1868/69. Schreiber unbekannt.

11 BBAW, Nachlass Schwarz, No. 471, Mitschrift der Vorlesung von K. Weierstraß: Elliptische Funktionen. 1870. Schreiber unbekannt.
} 


$$
\sum_{\mu=0}^{\mu=\infty} F_{\mu}\left(x_{1}, x_{2}, \ldots x_{\varrho}\right)=\sum_{(v)} A_{v_{1}, v_{2}, \ldots v_{\varrho}} x_{1}^{v_{1}} x_{2}^{v_{2}} \ldots x_{\varrho}^{v_{\varrho}}
$$

holds for every $\left(x_{1}, x_{2}, \ldots x_{\varrho}\right)$ from the said neighbourhood. ${ }^{12}$

And, for a very similar theorem (Weierstraß 1841, p. 73), he used the term gleichförmig convergent (uniform convergent). But, based on the lecture notes discussed here, the first trace of the term gleichmäßig was found in a lecture course on elliptic functions from 1870/71, and the term gleichförmig first appeared in a course on analytic functions from 1880/81 (see Sect. 5.6).

These indications strongly suggest that the 1841 article was significantly revised in terms of its mathematical terminology and notation, which makes the dating of the first occurrence of uniform convergence in 1841 highly questionable. ${ }^{13}$ This does not imply that Weierstraß did not use a concept of uniform convergence by this time; however, the terminology and notation related to uniform convergence in (Weierstraß 1841) was introduced years later in his lecture courses (see Sect. 5). As mentioned above, the scope of the corrections and revisions done for the publication in the Werke is unknown. Therefore, the first verifiable trace dates back to 1861, where Weierstraß introduced his concept of convergence at the same rate in a lecture course at the Gewerbeinstitut (Trade Institute) Berlin.

\section{The role of Weierstrass's lectures for the development of uniform convergence}

Before Weierstrass's appointment as a full professor, he published only a few research papers that potentially could deal with the notion of uniform convergence. ${ }^{14}$

The 1843 article, which was originally published in the Jahresbericht of the Progymnasium of Deutsch Crone, was taken over unchanged into the Werke. ${ }^{15}$ The same applies to the 1840 article, as Weierstraß himself stated (cf. Weierstraß 1894, p. 50). Neither work covers research relevant for our focus and the other two papers, espe-

\footnotetext{
12 Weierstraß (1841, pp. 70-1): „Es seien unendlich viele gewöhnliche Potenzreihen in bestimmter Aufeinanderfolge gegeben: $F_{0}\left(x_{1}, x_{2}, \ldots x_{\varrho}\right), F_{1}\left(x_{1}, x_{2}, \ldots x_{\varrho}\right), F_{2}\left(x_{1}, x_{2}, \ldots x_{\varrho}\right), \ldots$, und es werde angenommen, dass in einer bestimmten Umgebung $G$ der Stelle $(0,0, \ldots 0)$ nicht nur jede einzelne dieser Reihen, sondern auch deren Summe unbedingt und gleichmässig convergire. Bezeichnet man die Coefficienten von $x_{1}^{v_{1}} x_{2}^{v_{2}} \ldots x_{\varrho}^{v_{\varrho}}$ in $F_{\mu}\left(x_{1}, x_{2}, \ldots x_{\varrho}\right)$ mit $A_{v_{1}, v_{2}, \ldots v_{\varrho}}^{(\mu)}$ und setzt $\sum_{(\mu)} A_{v_{1}, v_{2}, \ldots v_{\varrho}}^{(\mu)}=A_{v_{1}, v_{2}, \ldots v_{\varrho}}$, so lässt sich zeigen, dass $A_{v_{1}}, v_{2}, \ldots v_{\varrho}$ einen endlichen Werth hat und für jedes der genannten Umgebung angehörige Werthsystem die Gleichung $\sum_{\mu=0}^{\mu=\infty} F_{\mu}\left(x_{1}, x_{2}, \ldots x_{\varrho}\right)=\sum_{(v)} A_{v_{1}, v_{2}, \ldots v_{\varrho}} x_{1}^{v_{1}} x_{2}^{v_{2}} \ldots x_{\varrho}^{v_{\varrho}}$ besteht."

13 The 1842 article Definition analytischer Functionen einer Veränderlichen vermittelst algebraischer Differentialgleichungen seems to have been revised as well. It was first published in 1894 and Weierstraß uses the term gleichförmig for uniform convergence (see Weierstraß 1842, p. 81).

14 See Weierstraß (1840, 1841, 1842, 1843a, b).

15 Today, Deutsch Crone is the Polish town of Wałcz.
} 
cially the 1841 paper, have probably been revised many years later, as discussed in Sect. 2.2.

However, some lecture notes from the period of his teaching activities at the Gewerbeinstitut Berlin have been preserved. These lectures do not cover the topic of analysis in the same depth as the later Berlin University lectures do, since they primarily served a mathematical education of a more practical type. During his teaching activities at the University of Berlin, he did not publish the basic concepts of his approach of analysis, but gave continuously revised lectures reflecting the state of his research. Therefore, the most important resource for investigating the Weierstrassian history of uniform convergence is given by the lecture notes from between 1864 and the early 1880s. They allow a profound insight into Weierstrass's teaching, which mark his most productive period of work. The level of authenticity is an important aspect and is not only determined by the author of the notes in question; from 1862, Weierstraß lectured seated due to health problems, and a selected student wrote his dictation on the blackboard. Therefore, alterations and errors could have crept in not only during writing down but also in the dictation process. With this in mind, the study of multiple notes of the same lecture course, but by different students is very enlightening.

Do we have any sources apart from the lecture courses from his period at the University of Berlin? The so-called mathematische Seminar was established in 1864, and thereafter Weierstraß gave advanced seminars for degree candidates. One can assume that his research topics were covered in these seminars, but we do not have any significant information on the subjects. ${ }^{16}$

\section{Weierstrass's lectures at the Gewerbeinstitut and their reception}

From 1856, Weierstraß taught at the Gewerbeinstitut and, due to his membership in the Royal Prussian Academy of Sciences (Berliner Akademie), he was also able to give some lectures at the University. In 1864, he finally became a full professor at the University of Berlin, and from 1864 his research results became increasingly (and mainly) known through his lectures. His students' lecture notes, which soon reached out mathematicians outside Berlin and indeed Germany, were the determining factors of this development.

Our knowledge of Weierstrass's work on uniform convergence is very incomplete for the time until he became a full professor at the University of Berlin. Before turning into a leading figure for the contemporary mathematicians in Germany and abroad, lecture notes of his students were not widespread. In addition, his lecture courses at the Gewerbeinstitut did not represent the state of his research, since that was not pertinent for a technical education. To shed some light into this period, we take a look at two lecture notes which come from courses held by Weierstraß at the Gewerbeinstitut. ${ }^{17}$

\footnotetext{
16 Cf. Viertel (2014, pp. 118 ff).

17 There is another script preserved at the BBAW, which seemed to be relevant. It is titled Theiler, Vorlesung von Weierstraß(?): Differentialrechnung. 1868, 1869, but it seems to represent someone else's lecture course. The university calendar reveals that Weierstraß did not give lectures on differential calculus, neither in the years 1868/69 nor in any other year as a professor at the University of Berlin. Lazarus I. Fuchs gave a lecture course on Differential- und Integralrechnung in 1868/69, and Ernst Reinhold Hoppe gave a course
} 
These are G. Schmidt's script on Differential- und Integralrechnung (1859) ${ }^{18}$ and H. A. Schwarz's lecture notes of Differentialrechnung $(1861)^{19}$. Schmidt's notes basically represent an introduction to differential and integral calculus, without a consideration of the concept of convergence. The 1861 lecture notes come from one of Weierstrass's most distinguished disciples and his eventual successor in Berlin, H. A. Schwarz, who described his notes as a "compact summary with weaknesses and imperfections." 20 What follows is the first occurrence of convergence at the same rate in Weierstrass's lectures. It is introduced in the context of the continuity theorem - i.e., Cauchy's sum theorem; yet, Cauchy's name is not evoked - and motivated by the (term by term) differentiation of infinite series:

A function is often composed of infinitely many other functions. E.g., a function can be represented by a sum or a product of infinitely many terms. We will now investigate how such a function represented by an infinite series can be differentiated; because the conclusion that the earlier developed rules readily apply to a sum of infinitely many terms is not rigorous and often even incorrect. Let there be a series whose individual terms are continuous functions of a single variable, and it is assumed that

$$
\varphi_{0}(x)+\varphi_{1}(x)+\varphi_{2}(x)+\varphi_{3}(x)+\cdots \text { in infinitum }
$$

is convergent for all $x$ between two given limits; then, we must first examine under which circumstances the series represents a continuous function of $x$. Only then, a series $s=t_{0}+t_{1}+t_{2}+t_{3}+\cdots$ in inf. is called convergent, if the difference between the whole series and the sum of the $n$ first terms $s-s_{n}$ can be made as small as one would like by increasing $n$, or if the sum $t_{n}+t_{n+1}+t_{n+2}+t_{n+3}+\ldots+t_{n+r}$, wherer is an arbitrary positive number, can be made smaller than any given quantity by increasing $n$, in such a way that the same $n$ is to be taken for all values $x$, and the property is retained, if $n$ is replaced by $n+m$, where $m$. is an arbitrary [?] $]^{21}$ number.

This shows that the kind of convergence is meant, which has since been called "convergence at the same rate" (author's emphasis). ${ }^{22}$

\section{Footnote 17 continued}

on Differentialrechnung und Reihentheorie in 1868 and 1869 each. Hoppe's lecture course is said to be based on his textbook (1865). It cannot be ruled out by now that these notes come from Fuchs's or Hoppe's lecture instead of Weierstrass's courses. Otherwise, it can be dated to the period of Weierstrass's teachings at the Gewerbeinstitut.

18 BBAW, Nachlass Schwarz, No. 453, G. Schmidt, Mitschrift der Vorlesung von K. Weierstraß: Differential- und Integralrechnung. 1859. 1 H., 35 B.

19 IML, H.A. Schwarz, Vorlesungsmitschrift von K. Weierstraß: Differentialrechnung. SS 1861.

20 See IML, H.A. Schwarz, Vorlesungsmitschrift von K. Weierstraß: Differentialrechnung. SS 1861, preface.

21 The reading of the word in Schwarz's manuscript is not entirely certain.

22 IML, H.A. Schwarz, Vorlesungsmitschrift von K. Weierstraß: Differentialrechnung. SS 1861, p. 64: „Es kommt häufig vor, dass eine Funktion aus unendlich vielen anderen zusammengesetzt ist. Es kann sich eine Funktion z. B. als eine Summe oder ein Produkt von unendlich vielen Gliedern darstellen lassen. Es soll nun untersucht werden, wie sich eine solche durch eine unendliche Reihe dargestellte Funktion 
In the above quotation, the first definition describes the convergence of a series without a specific rate of convergence ("[...] if [...] $s-s_{n}$ can be made as small as one would like by increasing $n$ "), whereas the second introduces convergence at the same rate (" $\ldots$, or if the sum $t_{n}+t_{n+1}+\ldots$ [...]"). In short, it is stated that $s_{n+r}-s_{n-1}$ should become small for arbitrary $n \geq N$ and arbitrary $r>0$. I interpret this as the Cauchyan uniformity condition. Here is a brief and modern definition that should be sufficient for the purpose of this article: Let $s$ be a convergent series of continuous functions from a set $X$ to a metric set $Y$, and let $s_{k}$ be the sum of the first $k$ terms. Then $s$ is called uniformly Cauchy, if for all $\varepsilon>0$, there exists a number $N>0$ such that for all $x \in X\left|s_{m}-s_{n}\right|<\varepsilon$ holds whenever $m, n>N$ (see discussion in Sect. 6). Assuming that $Y$ is complete, the series $s$ is also uniformly convergent. Since we have the completeness of the sets of real and complex numbers, which Weierstraß was aware of, the two concepts are equivalent.

The final sentence of the quote from p. 64 was probably added by Schwarz himself. On the one hand, this remark could have been added later by Schwarz to emphasize that the term "at the same rate" was used since 1861. On the other hand, it could indicate that Weierstraß introduced this new concept of convergence prior to his 1861 course (the German word "seither" can also mean "sth. has always been"). Schwarz possibly knew the new concept from another lecture course of Weierstraß at the Gewerbeinstitut. Still, it needs to be clarified how far this notion can be traced back in Weierstrass's works.

Following the continuity theorem, he gave a theorem about the term by term differentiation of infinite series: ${ }^{23}$

Let $f(x)=\varphi_{0}(x)+\varphi_{1}(x)+\varphi_{2}(x)+\ldots$ in inf . and $\psi(x)=\varphi_{0}^{\prime}(x)+\varphi_{1}^{\prime}(x)+\varphi_{2}^{\prime}$

$(x)+\ldots$ in inf. be two series convergent at the same rate, whose addends are continuous functions of $x$. So, let $f(x)$ and $\psi(x)$ be continuous functions of $x$ and the terms of the series $\psi(x)$ be such that each of them is the derivative

Footnote 22 continued

differentiiren lässt; denn der Schluss, dass die früher entwickelten Regeln ohne weiteres auch für eine Summe aus unendlich vielen Gliedern gelten, ist nicht strenge und häufig sogar unrichtig.

Es sei nun eine Reihe gegeben, deren einzelne Glieder stetige Funktionen einer veränderlichen Grösse seien und es sei angenommen,

$\varphi_{0}(x)+\varphi_{1}(x)+\varphi_{2}(x)+\varphi_{3}(x)+\cdots$ in infinitum

dass dieselbe convergent sei für alle zwischen zwei gegebenen Grenzen liegende Werthe von $x$, so ist zunächst zu untersuchen, unter welchen Umständen diese Reihe eine continuirliche Funktion von darstellt. Eine Reihe $s=t_{0}+t_{1}+t_{2}+t_{3}+\cdots$ in inf. heisst überhaupt dann convergent, wenn sie so beschaffen ist, dass die Differenz der ganzen Reihe und der Summe der $n$ ersten Glieder $s-s_{n}$ durch Vergrösserung von $n$ so klein gemacht werden kann, als man immer will, oder wenn die Summe von $r$ auf das $n$-te Glied folgenden Gliedern $t_{n}+t_{n+1}+t_{n+2}+t_{n+3}+\cdots+t_{n+r}$, wo $r$ eine ganz beliebige positive Zahl bedeutet, durch Vergrösserung von $n$ kleiner als jede nur angebbare Grösse gemacht werden kann, und zwar so, dass für alle Werthe $x$ dasselbe $n$ zu nehmen ist, wobei die Eigenschaft auch erhalten bleibt, wenn statt $n n+m$ gesetzt wird, wo $m$ beliebig [?] Zahl.

Der Sinn zeigt, dass diejenige Art der Convergenz gemeint ist, welche seither mit dem Namen 'Convergenz in gleichen Grade' bezeichnet wird.“

23 According to Kurt Richter (1976, p. 98), Weierstraß was the first to provide a solution to this question: "[Die Frage der Möglichkeit der gliedweisen Differentiation und Integration von Reihen] wurde erst durch das Wirken von Weierstrass ersten Lösungen zugeführt." In other words: Cauchy had missed to require conditions for term by term differentiations of a series. 
of the corresponding addend of the series $f(x)$. Then, it should be proved that $\psi(x)$ is the derivative of $f(x) .{ }^{24}$

The historian of mathematics Pierre Dugac considered Weierstrass's proof to be extraordinary for the time (Dugac 2003, p. 126). ${ }^{25}$ He also claimed that Weierstraß was partly inspired by a letter from Niels Henrik Abel to the Norwegian mathematician Bernt Holmboe dated January 16, 1826 (Dugac 2003, p. 127). In this letter, Abel complained how careless mathematicians use to deal with infinite series and explicitly showed that one cannot always differentiate a series term by term (Holmboe 1839, p. 268).

From 1861 the new concepts of convergence at the same rate were adopted by others, e.g., by Ludwig Wilhelm Thomé who studied in Berlin from the summer of 1863 and who was held in high esteem by his teacher Weierstraß (cf. Biermann 1988, p. 129, and Viertel 2014, p. 113). Thomé possibly knew Weierstrass's lecture on the differential calculus (1861) from copies that were already circulating. In his work Über die Kettenbruchentwicklung der Gausschen Function $F(\alpha, 1, y, x)$ (1866), Thomé discussed the differentiability of the series $1+\sum_{r=1}^{\infty} \frac{a_{1} a_{2} \ldots a_{r} x^{r}}{N_{r} N_{r+1}}$, where $N_{r}$ represent specific values of $F(\alpha, 1, y, x)$ (p. 333 f.). After substituting with $x=\frac{4 z}{(1+z)^{2}}$, he obtained the unconditional and uniform convergence of the corresponding series $(1+z) \sum_{r=\varrho}^{\infty} \frac{a_{1} a_{2} \ldots a_{r}(4 z)^{r}}{\Phi_{r}(z) \Phi_{r+1}(z)}$ by a majorant series ${ }^{26}$, which also holds in a very similar way for those series obtained by term by term differentiation (Thomé 1866, p. 334).

Given Thomé's significance for the reception, one can infer that Weierstraß probably had used such a preliminary stage of the Weierstraß $M$-test before 1866 . Nonetheless, this comparison test for uniform convergence of series was not a part of the applications that Weierstraß was going to introduce in his further lecture courses in Berlin. Finally, Thomé gave a short explanation of the term im gleichen Grade:

Every single ones of these series [converges] at the same rate in the assumed region, which means that the sum of the later terms simultaneously becomes infinitely small everywhere. ${ }^{27}$

The formulation "simultaneously ... everywhere" indicates the difference to pointwise convergence, but overall Thomé's description remains unclear, e.g., the sum of the "later terms" could refer to the sum of the remainder as well as to a finite number

24 IML, H.A. Schwarz, Vorlesungsmitschrift von K. Weierstraß: Differentialrechnung. SS 1861, p. 68: „Es seien nun $f(x)=\varphi_{0}(x)+\varphi_{1}(x)+\varphi_{2}(x)+\ldots$ in inf. und $\psi(x)=\varphi_{0}^{\prime}(x)+\varphi_{1}^{\prime}(x)+\varphi_{2}^{\prime}(x)+\ldots$ in inf. zwei in gleichem Grade convergente Reihen, deren Glieder stetige Funktionen von $x$ sind, also $f(x)$ und $\psi(x)$ seien stetige Funktionen von $x$ und es seien die Glieder der Reihe $\psi(x)$ so beschaffen, dass jedes die Ableitung des entsprechenden Gliedes der Reihe $f(x)$ ist, so soll bewiesen werden, dass $\psi(x)$ die Ableitung von $f(x)$ ist."

25 Dugac mistakenly cites Pasch's script, but he referred to the corresponding passages in Schwarz's notes (see Dugac 2003, pp. 126 f.).

26 Thomé assumes the existence of a number $g$ for which the absolute values of $\left(\Phi_{r}(z) \Phi_{r+1}(z)\right)^{-1}$ are $<g$ for $r \geq \varrho$ and for an area inside the open unit disk. Since he already proved the unconditional convergence of the power series $g(1+z) \sum_{r=\varrho}^{\infty} a_{1} a_{2} \ldots a_{r}(4 z)^{r}$ for all values inside the open unit disk, he concludes the unconditional and uniform convergence of $(1+z) \sum_{r=\varrho}^{\infty} \frac{a_{1} a_{2} \ldots a_{r}(4 z)^{r}}{\Phi_{r}(z) \Phi_{r+1}(z)}$.

27 Thomé 1866, p. 334: ,jede einzelne dieser Reihen [convergirt] in dem angenommenen Bereiche im gleichen Grade, d. h. die Summe der späteren Glieder wird dort überall gleichzeitig unendlich klein.“ 
of terms in the form of $s_{m}-s_{n}$. He also referred to the permutability of summation and differentiation (and integration respectively) of uniform convergent series-theorems he certainly adopted from Weierstraß:

But if one differentiates a series converging at the same rate by its terms, then, if one obtains again a series converging at the same rate, the latter is known to be the derivative of the continuous function represented by the original series, according to the theorem on the definite and term by term integration of a series converging at the same rate. ${ }^{28}$

In conclusion, his original series in $1+\sum_{r=1}^{\infty} \frac{a_{1} a_{2} \ldots a_{r} x^{r}}{N_{r} N_{r+1}}$ can be derived term by term. Thomé's article shows that the new meaning of convergence at the same rate was already a part of mathematical research outside of the "Berlin lectures" in 1866. Despite the introduction of this new notion in mathematical research, Hoppe (1865) referred to the term im gleichen Grade for comparing the speed at which two infinite series converge. Because of his claim to provide a "rigorous introduction" to infinitesimal calculus, one can assume that he was not aware of Weierstrass's research. Therefore, Hoppe's Lehrbuch indicates that the concept of uniform convergence was not yet commonly known to authors of textbooks.

\section{The Berlin Lectures on analytic and elliptic functions}

Weierstrass's mathematical work was almost only accessible through his lecture courses at the University of Berlin. ${ }^{29}$ His lectures were delivered as a cycle of four lectures courses that contain most of his mathematical work. The currently accessible lecture notes are preserved at different locations such as libraries, mathematical institutes or other archives. Some of these notes are privately owned. With regard to the notion of uniform convergence, the lectures on analytic and elliptic functions are the most relevant. According to the university calendar for 1865-1883, these lectures were held cyclically as follows. Individual lecture courses are highlighted by an asterisk in case that students' notes are available:

- Lecture courses on analytic functions: WS $1865 / 66^{*}$, SS $1868^{*}$, SS 1870, SS 1872, SS $1874^{*}$, SS 1876, SS $1878^{*}$, SS 1880, WS 1880/81*, WS 1882/83* $1886^{*}$.

- Lecture courses on elliptic functions: WS 1866/67, WS 1868/69*, WS 1870/71*, WS 1872/73, WS 1874/75*, WS 1876/77, WS 1878/79, SS 1881, SS 1883.

Kurt Richter (1976, p. 143 ff.) was the first to give a mathematical-historical analysis of some lecture notes in regard to the history of uniform convergence, but he focused

\footnotetext{
28 Thomé 1866, p. 334: „Differentiirt man aber eine in einem stetigen Bereiche in gleichem Grade convergirende Reihe in den einzelnen Gliedern, so ist, wenn man dadurch eine ebenso convergirende Reihe erhält, bekanntlich letztere die Ableitung der durch die erstere ausgedrückten stetigen Function nach dem Satze über die bestimmte Integration einer in gleichem Grade convergenten Reihe durch Integration der Glieder."

29 However, there are publications worth mentioning for a discussion of uniform convergence. They were published in the series of the Königl. Preussische Akademie der Wissenschaften zu Berlin or in a revised edition in his Werke. One of these articles, Zur Functionenlehre (1880), was published in the Monatsberichte of the Berlin Academy and can be considered an authentic and unrevised work. According to Richter (1976, p. $196 \mathrm{ff}$.), this article alone led to a wide reception and acceptance of the notion of uniform convergence.
} 
solely on the courses on analytic functions from SS 1874, SS 1878, WS 1882/83 and 1886.

In the following sections, relevant lecture notes of both elliptic and analytic functions as well as other selected sources will be discussed to achieve a deeper analysis and understanding of the development of uniform convergence in Weierstrass's work. ${ }^{30}$

Among the lecture notes used for this article, a rather interesting phenomenon occurs: We have two lecture notes from 1868 and a single script of elliptic functions (WS 1868/69) ${ }^{31}$ from an unknown note-taker, in which uniform convergence is completely absent. The scripts from the 1868 course on analytic functions (summer 1868) come from two different students, Wilhelm Killing and Ludwig Kiepert, who both graduated under Weierstraß in $1870 .{ }^{32}$ The lack of the notion of uniform convergence could be related to Kiepert und Killing not seeing the enormous relevance of this new concept and, therefore, missing it in their copies. In fact, however, I did not find topics in the two scripts that would have needed uniform convergence.

Note that Kiepert's and Killing's lecture notes are very different in length and structure, which may be due to the fact that they reworked their original notes to different degrees.

The phenomenon of different scripts from the same course occurs again in 1878: There are scripts by Hurwitz and by Rudio. In the editor's preface, Adolf Hurwitz's script of a course on analytic functions is described as an "authentic reproduction"33 of the lecture course. And we know that Salvatore Pincherle used a copy of Hurwitz's notes for his work Saggio di una introduzione alla theoria delle funzioni analytiche secondo i principii di Prof. C. Weierstrass (1880). Surprisingly, Ferdinand Rudio's script differs significantly from Hurwitz's version and one might doubt that they come from the same lecture course. But, according to the university calendar, a lecture named Theorie der analytischen Functionen was only held during the summer semester. My research on the Abgangszeugnisse (leaving certificates) of Rudio and Hurwitz in the Berlin University Archive verifies both were admitted to this particular course.

\subsection{Moritz Pasch's script 1865}

The earliest original lecture notes discussed here come from Weierstrass's student Moritz Pasch, and they are dated to 1865 . Pasch first studied in his hometown at the University of Breslau, where he graduated in 1865. He then moved to the University of Berlin to study under Leopold Kronecker and Weierstraß; in 1875, he became a

\footnotetext{
${ }^{30}$ For a discussion of the other mathematical issues in the lecture courses on analytic functions, see (Bottazzini 2016). It is based on scripts from the summer semesters of 1868, 1874, 1878 and 1886.

31 BBAW, Nachlass Schwarz, No. 470.

32 Killing took up his studies at Münster and moved to the University of Berlin for the WS 1867/68. After his graduation and thanks to Weierstrass's recommendation, he was appointed teacher of mathematics in Braunsberg at the Lyceum Hosianum in 1882 before he finally returned to Münster to become a professor at the university in 1892. Kiepert studied mathematics during 1865-1871 at Breslau and Berlin and became a full professor at the Technical College of Hannover in 1879 after he had taken appointments at the University of Freiburg (due to Weierstrass's recommendation) and the Technical College of Darmstadt. Kiepert's script is preserved in Schwarz's Nachlass.

33 Weierstraß 1878, p. xiii.
} 
full professor in Breslau. In his script on analytic functions, we find both a continuity theorem and a theorem about the integration of infinite series of continuous, real functions, which make use of uniform convergence (see Fig. 2).

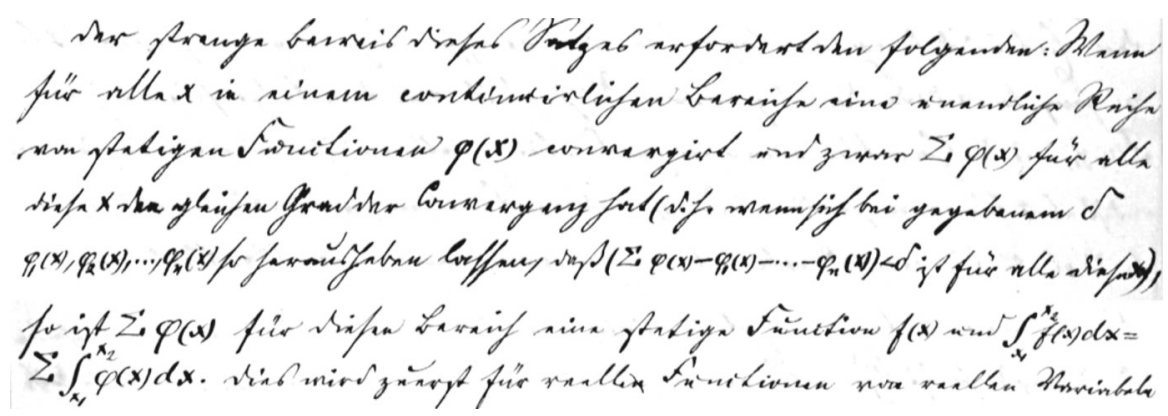

Fig. 2 Nachlass Moritz Pasch, Signatur I, 19, p. 28v-29r

Note that the parentheses around the term $\sum \varphi(x)-\varphi_{1}(x)-\cdots-\varphi_{n}(x)$ represent the absolute value. An English translation of Fig. 2 is as follows:

If an infinite series of continuous functions $\varphi(x)$ converges for all $x$ of a continuous region and $\sum \varphi(x)$ converges at the same rate for all these $x$ (that is, if for a given $\delta$, one finds $\varphi_{1}(x), \varphi_{2}(x), \cdots, \varphi_{n}(x)$ such that $\left(\sum \varphi(x)-\varphi_{1}(x)-\cdots-\varphi_{n}(x)\right)<\delta$ holds for every such $\left.x\right)$, then $\sum \varphi(x)$ is a continuous function $f(x)$ and $\int_{x_{1}}^{x_{2}} f(x) \mathrm{d} x=\sum \int_{x_{1}}^{x_{2}} \varphi(x) \mathrm{d} x$.

We find analogous statements and a theorem on the term by term differentiation for analytic functions, but without proofs. ${ }^{34}$ This first appearance of a definition of uniform convergence (not uniformly Cauchy) basically says that the absolute value of the sum of the remainder $s-s_{n}$ should become $<\delta$ for a $n=n(\delta)$, but not explicitly for every number or infinitely many numbers $\geq n$. Indeed, the existence of only one $n=n(\delta)$ is sufficient for a proof of the continuity of $\sum \varphi(x)$. However, it remains questionable if Weierstraß meant $s-s_{n}<\delta$ to hold just for one $n=n(\delta)$. We find further examples of this variation in later lecture notes and also with regard to the Cauchyan uniformity condition. Hence, I will not point out and discuss every occurrence.

Furthermore, Pasch's definition is introduced in parentheses, which could mean that this concept was introduced earlier than in 1865-otherwise one would have to expect a more detailed introduction by Pasch.

\footnotetext{
34 Nachlass Moritz Pasch, Signatur I, 19, p. 29v: „Wenn für alle Punkte innerhalb eines continuirlichen Bereiches mit Ausschluß von einzelnen eine Summe von unendlich vielen analytischen Functionen $\sum \varphi$ $(x)$ convergirt und für alle von gleichen Grad der Convergenz besitzt, so stellt sie eine analytische Function $f(x)$, die man erhält, indem man jedes $\varphi$ entwickelt und die gleichnamigen Glieder zusammenzieht, und es ist $f^{(v)}(x)=\sum \varphi^{(v)}(x)$. (Bei mehr mehrdeutigen Functionen sind convergirende Werthe zu nehmen.) “

Nachlass Moritz Pasch, Signatur I, 19, p. 30v: „Wenn für alle Punkte eines Kreises mit Ausschluß von einzelnen eine unendliche Summe $\sum \varphi(x)$ von eindeutigen analytischen Functionen convergirt und denselben Grad der Convergenz behält, so daß $\sum \varphi(x)=f(x)$ eine analytische Function für dieselben Punkte ist, so hat $\operatorname{man} \int_{a}^{x} f(u) d u=\sum \int_{a}^{x} \varphi(u) d u$, wo alle Integrationen auf demselben Wege innerhalb jedes Kreises auszuführen sind. (Versteht man unter $\varphi(x)$ mehrdeutige Functionen, so sind convergirende Werthe zu nehmen.)“
} 


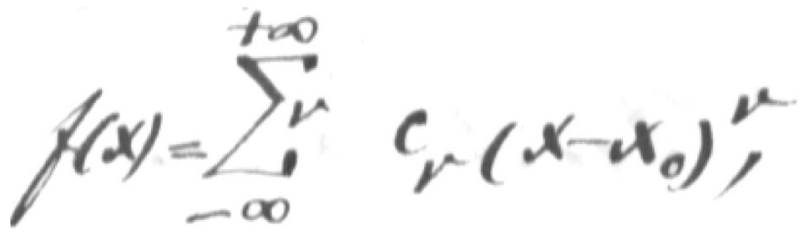

Fig. 3 Weierstrass's notation for a Laurent series, in Pasch's script, p. 28v

Note that the common variants of index notations in today's mathematics (e.g., setting the index of summation under the summation symbol) were not established yet and, therefore, either completely absent or implemented differently (see Fig. 3).

\subsection{Uniform convergence in a script of 1870/71}

According to the university calendar, this script of a lecture course on elliptic functions from Schwarz's Nachlass comes from the WS 1870/71. The author remains unknown. In contrast to the 1865 script by Pasch, Weierstraß explicitly emphasized the relevance of uniform convergence here:

If, however, we have to construct the integral of an infinite sum denoted by $\sum \varphi(t)$, we can prove a very general theorem, which holds for most cases of applications [meaning the interchangeability of summation and integration; K.V.]. The conditions under which we can obtain a convergent series by integration are not yet well known.

We first understand by $\varphi(t)$ only real functions of a real variable and we have to assume in any case that $\sum \varphi(t)$ converges for all $t$ considered. But this is not sufficient, but the series must converge at the same rate, i.e., it must be possible to separate a certain number of terms of the series such that the sum of the remainder becomes smaller than $\delta$ for all values considered or, in other words, the sum of the remainder must have the same rate of exactness for all values of $t$ considered. ${ }^{35}$

This introduction seems to describe convergence at the same rate as in Pasch's script, though it is mostly verbal and lacks the absolute values: The sum of the remainder (die Summe der übrigen) should become small after separating a "certain number of terms," meaning $s-s_{n}<\delta$ for a number $n=n(\delta)$. Additionally,

\footnotetext{
35 BBAW, Nachlass Schwarz, No. 471, Mitschrift der Vorlesung von K. Weierstraß: Elliptische Funktionen. 1870. Schreiber unbekannt, pp. 126-7: „Haben wir dagegen das Integral einer unendlichen Summe, die wir mit $\sum \varphi(t)$ bezeichnen wollen, zu bilden, so können wir einen sehr allgemeinen Satz beweisen, der in den meisten Fällen der Anwendung ausreicht. Die Bedingungen, unter denen man durch Integration eine convergente Reihe ableiten kann, sind noch nicht genau bekannt.

Wir verstehen zunächst unter $\varphi(t)$ nur reelle Functionen einer reellen Veränderlichen und müssen dabei jedenfalls annehmen, daß $\sum \varphi(t)$ convergirt für alle $t$, die wir betrachten. Dies reicht aber nicht aus, sondern die Reihe muss in gleichem Grade convergent sein, d. h. es muss möglich sein, eine bestimmte Zahl von Gliedern der Reihe so abzutrennen, daß die Summe der übrigen für alle betrachteten Werthe stets kleiner ist als $\delta$, oder anders ausgedrückt, die Summe derselben Glieder muß für alle betrachteten Werthe von $t$ denselben Grad von Genauigkeit haben.“
} 
this type of convergence is uniquely named convergence with the "same rate of exactness," which is not used again in this manner in later lectures. Weierstraß gave several applications of the concept: The uniform convergence of a series of functions $\varphi(t)$ yields the uniform convergence of the sum of integrals $\int_{\tau}^{\tau^{\prime}} \varphi(t) \mathrm{d} t$, if they exist:

[...] if $\sum \varphi(t)$ converges at the same rate for all possible values of $t$, then the sum of the terms $\psi=\int_{\tau}^{\tau^{\prime}} \varphi(t) \mathrm{d} t$, whose existence we assume, also converges, since we can prove that a finite number of the terms $\psi_{1} \ldots \psi_{n}$ can be separated in such a way that the sum of arbitrarily many remainder terms satisfies $\left|\psi_{n+1}+\cdots+\psi_{n+m}\right|<\delta$, if $\delta$ denotes a number assumed arbitrarily small. [...] Thus, it is shown that if $\sum \varphi(t)$ converges at the same rate, the same property holds for $\sum \psi(t){ }^{36}$

Here we have a variation of the Cauchyan uniformity condition, since the inequality $\left|s_{n+m}-s_{n}\right|<\delta$ should hold for a number $n=n(\delta)$ and arbitrary values of $m$. But it seems as if $\left|s_{n+m}-s_{n}\right|<\delta$ is only required to hold for one $n$, which is sufficient for this theorem.

It was unusual for Weierstraß to specify the exact domains of convergence in a rigorous way, and here he just referred to all values considered. The following theorem gives another example: "If the infinite sum $\sum f(x)$ converges at the same rate for all points in the neighbourhood of a certain point, then any definite integration on each term can be performed." ${ }^{37}$ Functions with complex variables are also considered similarly: "If the term by term differentiation of a series produces an apparently incorrect result, we must conclude that the series does not converge at the same rate for an area in the complex plane." 38 In the next application, it is stated that a uniformly convergent series of rational functions is again rational, if only finitely many of these functions have poles in the domain. The uniform convergence should hold in the neighborhood of every point:

If there is only a finite number of functions $\varphi(x)$ within this area bounded by the line just mentioned, which become infinitely large for points of this area, then $\sum \varphi(x)$ is a function of rational character, provided that the condition of uniform convergence holds in the neighbourhood of every point $x_{0} .{ }^{39}$

36 BBAW, Nachlass Schwarz, No. 471, pp. 127-8: „Wenn aber $\sum \varphi(t)$ für alle in Betracht kommenden Werthe von $t$ in gleichem Grade convergirt, so ist auch die Summe der Größen $\psi=\int_{\tau}^{\tau^{\prime}} \varphi(t) \mathrm{d} t$, deren Existenz wir voraussetzen, convergent, denn wir können zeigen, daß es möglich ist, eine endliche Zahl der Größen $\psi_{1} \ldots \psi_{n}$ so abzutrennen, daß die Summe beliebig vieler der übrigen $\left|\psi_{n+1}+\cdots+\psi_{n+m}\right|<\delta$ wird, wenn $\delta$ eine beliebig klein angenommene Größe bezeichnet. [...] Somit ist gezeigt, daß, wenn $\sum \varphi(t)$ im gleichen Grade convergent ist, $\sum \psi(t)$ dieselbe Eigenschaft hat.“

37 BBAW, Nachlass Schwarz, No. 471, p. 130: „Ist die unendliche Summe $\sum f(x)$ für alle Punkte in der Umgebung eines gewissen Punktes im gleichen Grad convergent, so läßt sich jede bestimmte Integration an den einzelnen Gliedern ausführen."

38 BBAW, Nachlass Schwarz, No. 471, p. 146: „Wenn beim differenzieren einer Reihe an den einzel[e]n Gliedern offenbar ein unrichtiges Resultat hervorgeht, so müssen wir schließen, daß die Reihe nicht für ein komplexes Gebiet im gleichen Grade convergirt."

39 BBAW, Nachlass Schwarz, No. 471, p. 148: „Wenn es nun innerhalb dieser von der eben erwähnten Linie begrenzten Fläche nur eine endliche Anzahl von Functionen $\varphi(x)$ [von rationalem Character; K.V.] giebt, 
He goes on to the following theorem by setting a disk centered at zero as a potential domain of convergence:

If we describe a circle with a finite radius around the zero point, this $\sum \varphi(x)$ converges at the same rate in the neighbourhood of all points $x_{0}$, except those for which $\varphi(x)$ becomes infinite, and only a finite number of these terms $\varphi$ become infinitely large for points within this circle. ${ }^{40}$

It is worth noting that the first of these quotes is the first occurrence of the term gleichmäßig (uniform) in Weierstrass's lectures, which is also the most common term in German textbooks today. Weierstraß used both formulations im gleichen Grade and gleichmäßig to denote uniform convergence, but there seem to be no differences in their meaning. The first term, originally used by Gudermann, disappears in all subsequent lecture notes on elliptic and analytic functions from 1870 onward and the formulation gleichmäßig became the most used in his lecture courses.

\subsection{The development of uniform convergence between 1870 and 1874}

The date when Weierstraß changed his terminology from im gleichen Grade to gleichmäßig is still unknown, but I assume it happened before 1870/71. At least, the applications of uniform convergence in the script of the WS 1870/71 course indicate a previous introduction in the course on analytic functions of 1870. Carl Johannes Thomae was the first to refer to gleichmäßige Convergenz in his textbook (1870), says Richter (1976, p. 187 f.). According to the university calendar, Weierstraß also held courses on both analytic and elliptic functions in the summer of 1872 and in the WS $1872 / 73$, but for the terms from $1870 / 71$ to 1873 , there are no lectures notes known.

In this case, publications by Weierstrass's colleagues and students can give further insights. H. A. Schwarz was a student of Weierstraß until 1864, and then he stayed in Berlin until 1867. In 1873, he published an article introducing the series $\sum_{n} \frac{\left[2^{n} x\right]+\sqrt{2^{n} x-\left[2^{n} x\right]}}{4^{n}}$, which represents a unique and everywhere continuous function, whose differential quotient is unbounded in every interval. In his lecture courses from 1861 , Weierstraß had already rejected the general conviction that continuous functions are differentiable. Schwarz pointed out:

In 1861, Mr. Weierstrass gave the correct exposition of the true facts in the lectures on differential and integral calculus, which he held at the Trade Institute, according to which all attempts to generally prove the existence of a derivative for continuous functions of a real variable must be considered unsuccessful without exception. $^{41}$

\section{Footnote 39 continued}

die für Punkte dieser Fläche unendlich groß werden, so ist $\sum \varphi(x)$ eine Function von rationalem Character, vorausgesetzt, daß in der Umgebung jedes Punktes $x_{0}$ die Bedingung der gleichmäßigen Konvergenz erfüllt ist."

40 BBAW, Nachlass Schwarz, No. 471, p. 148: „Beschreiben wir nun um den Nullpunkt einen Kreis mit endlichem Radius, so convergirt dieses $\sum \varphi(x)$ in der Umgebung aller Punkte $x_{0}$, ausgenommen die, für welche $\varphi(x)$ unendlich wird, in gleichem Grade, und es werden für Punkte innerhalb dieses Kreises nur eine endliche Anzahl dieser Größen $\varphi$ unendlich groß.“

41 Schwarz 1873, p. 269: „Herr Weierstrass [hat] im Jahre 1861 in den Vorlesungen, welche derselbe in dem Gewerbeinstitute in Berlin über Differential- und Integralrechnung hielt, die richtige Darlegung des wahren 
Furthermore, Weierstraß had read a paper to the Berlin Academy in March 1872, where he gave his famous example of a continuous but nowhere differentiable function. ${ }^{42}$ In order to prove continuity, Schwarz considered the convergence of the mentioned series:

The series converges at the same rate for all possible values of $x$. Therefore, the property of uniqueness and continuity, which the individual terms of the series possess as functions of $x$, is also transferred to their sum. ${ }^{43}$

As we see, he referred to uniform convergence, and, as a close colleague of Weierstraß, one would expect him to use the same term for uniform convergence as his former teacher did in his research. ${ }^{44}$ Under this assumption, Weierstraß could have referred to convergence at the same rate at least until 1873.

\subsection{Georg Hettner's lecture notes from 1874}

The German mathematician Georg Hermann Hettner was born in Jena, studied first in Leipzig and then moved to the University of Berlin. He earned himself a good reputation with Weierstraß and was occasionally granted the honor of writing Weierstrass's lectures on the blackboard. ${ }^{45}$ With that in mind, his script on analytic functions (1874) can be considered a fairly authentic reproduction of the original course. A novelty of Hettner's script is the new way of introducing uniform convergence by addressing (what is called today) the double series theorem: "We can now find another criterion for converting a sum of power series into a power series. For this, we must introduce the new concept of uniformly convergent series." 46 We take a look at how he defined this notion:

We had assumed that $\sum f(x)$ [representing a power series; KV] converges in the neighbourhood of $a$. Therefore, if we give to $x$ a particular value of this neighbourhood, it is always possible to separate a finite number of terms in such a way that the sum of the remainder is smaller than an arbitrarily small quantity

Footnote 41 continued

Sachverhalts gegeben, gemäss dem alle Versuche, die Existenz einer Ableitung für stetige Functionen eines reellen Argumentes allgemein zu beweisen, ohne Ausnahme als verfehlt betrachtet werden müssen."

42 However, Thiele erroneously attributes priority for the indication of such a type of function to Schwarz: "it was not before 1874 that [Schwarz] actually found a counterexample, as read in a letter of April 19, 1874“ (Thiele 2008, p. 406). Strangely, Thiele is not aware of Weierstraß having communicated the first counterexample in 1872 .

Moreover, Weierstraß had pointed out to Paul du Bois-Reymond that Schwarz's function does not have the same properties because it has a differential quotient for infinitely many points (Schubring 2012, p. 572 f.).

43 Schwarz 1873, p. 272: „Die Reihe convergirt für alle in Betracht kommenden Werthe von $x$ in gleichem Grade. Aus diesem Grunde überträgt sich die Eigenschaft der Eindeutigkeit und Stetigkeit, welche die einzelnen Glieder der Reihe als Functionen von $x$ besitzen, auch auf die Summe derselben.“

44 Weierstrass's correspondence with Schwarz is dated to 1866-1893 (cf. Thiele 2008).

45 Biermann (1988, p. 144): „Er gehörte zu jenen Studenten, denen von Weierstraß zeitweise das verantwortungsvolle Amt eines Anschreibers an der Tafel übertragen wurde“.

46 UB, Weierstraß 1874, p. 502: „Wir können jetzt noch ein andres Kriterium für die Umwandlung einer Summe von Potenzreihen in eine Potenzreihe finden. Wir müssen dazu den neuen Begriff der gleichmässig konvergenten Reihen einführen“ (author's emphasis). 
$\delta$. If, after assuming a certain, arbitrarily small quantity $\delta$ for every value of $x$ in the neighborhood of $a$ and after separating the same finite number of terms from $\sum f(x)$, the sum of the remaining terms is less than $\delta$, then we say $\sum f(x)$ is not only convergent in the neighborhood of a, but uniformly convergent. ${ }^{47}$

Weierstraß evidenced here different practices in mathematical rigor: On the one hand, we have a formalization for the upper bound for the sum of the remainder; on the other hand, there is no mathematical formalization used for the said sum such as he had used in previous lectures (see Pasch's script and the 1870/71 script on elliptic functions). In a modern, condensed form, he said that sum $s-s_{n}$ should be smaller than $\delta$ for a $n=n(\delta)$, which is similar to the definition found in Pasch's script, apart from the missing absolute values.

Furthermore, this introduction shares some similarities to a passage in Eduard Heine's article Ueber trigonometrische Reihen (1870): Heine also explicitly distinguished between (pointwise) convergence and uniform convergence by introducing the latter as an expansion of the concept of convergence:

A series of terms $g_{1}, g_{2}, g_{3}, \cdots g_{m}$ is called convergent, if, for an assignable value $n$ and for always increasing values of it, the sum $g_{n}+g_{n+1}+g_{n+2}+\cdots+g_{n+m}$ sinks below any arbitrarily given value $\varepsilon$ different from zero for every positive number given to $m$.

If the terms $g$ depend on a single variable $x$, which is allowed to pass through all values from $\alpha$ to $\beta$ (including $\alpha, \beta$ ), then, within these limits, the series is called convergent at the same rate, if the criterion of convergence holds for each given $\varepsilon$, while $x$ passes through all values, for the same $n$; one has only to take another value for $n$ if another $\varepsilon$ is given. ${ }^{48}$

Heine's presentation of convergence at the same rate (in a closed interval) describes the Cauchyan uniformity condition in almost the same way as Schwarz referred to it in 1861: In modern terms, the inequality $s_{n+m}-s_{n-1}<\varepsilon$ should hold for every $n \geq N=N(\varepsilon)$ and every $m$.

Did he attend to Weierstrass's lecture courses? Probably not, since he graduated in 1842 and was appointed as a professor in Halle on the September 6, 1856. Nonetheless, as a friend of Weierstraß, he likely knew some of the existing lecture notes. Heine's

\footnotetext{
47 UB, Weierstraß 1874, p: 502 f.: ,In der Umgebung von $a$ hatten wir $\sum f(x)$ als konvergent angenommen. Legen wir daher dem $x$ einen bestimmten Wert dieser Umgebung bei, so ist es stets möglich eine endliche Anzahl Glieder so auszuscheiden, dass die Summe der übrigen kleiner als eine beliebig kleine Grösse $\delta$ ist. Wenn nun nach Annahme einer bestimmten, beliebig kleinen Grösse $\delta$ für jeden Wert von $x$ in der Umgebung von $a$ nach Ausscheidung derselben endlichen Anzahl Glieder aus $\sum f(x)$ die Summe der übrig gebliebenen Glieder kleiner als $\delta$ ist, so sagen wir $\sum f(x)$ ist in der Umgebung von $a$ nicht nur konvergent, sondern gleichmässig konvergent."

48 Heine (1870, p. 355 f).: ,Eine Reihe von Gliedern $g_{1}, g_{2}, g_{3}, \cdots g_{m}$ heisst convergent, wenn von einem angebbaren Werthe $n$ an, für stets wachsende Werthe von $n$, die Summe $g_{n}+g_{n+1}+g_{n+2}+\cdots+g_{n+m}$ unter jede beliebig gegebene von Null verschiedene Grösse $\varepsilon$ herabsinkt, welche positiven Werth man auch $m$ geben möge. Hängen die Glieder g von eine Veränderlichen $x$ ab, welche alle Werthe von $\alpha$ bis $\beta$ (incl. $\alpha, \beta$ ) durchlaufen darf, so heisst die Reihe innerhalb dieser Grenzen in gleichem Grad convergent, wenn das Criterium der Convergenz für jedes gegebene $\varepsilon$, während $x$ alle Werthe durchläuft, durch dasselbe $n$ erfüllt wird; für $n$ hat man erst dann einen anderen Werth zu nehmen, wenn ein anderes $\varepsilon$ gegeben ist."
} 
publication includes both terms gleichmäßig and in gleichen Grade and Weierstraß most likely used both terms before $1870 .{ }^{49}$

\subsection{Two lecture notes on analytic functions from 1878}

\subsubsection{Rudio's script}

Until 1874, Weierstraß used uniform convergence as a tool to solve problems in the context of infinite series of continuous functions, originating from the continuity theorems. The lecture courses on analytic functions (1878) — and the notes taken by Ferdinand Rudio and Adolf Hurwitz-show an increasing focus on uniform convergence as a more original concept.

Born in Wiesbaden, Germany, Rudio first studied mathematics and physics at the Federal Polytechnic College of Zürich (Polytechnikum Zürich) before he moved to Berlin in 1877. Three years later, he finished his doctorate. In this period, he attended the seminars of Weierstraß. He then returned to the Polytechnikum, and in 1889, he became a full professor of mathematics. Due to his contributions, he was awarded an honorary doctorate by the University of Zürich in 1919. The notion of uniform convergence takes up a more important part in his script than in previous lecture notes. It has become a subject of its own as it is introduced in a section titled "Erweiterung des Functionenbegriffs. Gleichmäßige Konvergenz." ${ }^{50}$ The following definition, specified for functions with several variables, shows a new level of contextualization and, as well, a possible misunderstanding by Rudio:

We define this important notion as follows: the sum of infinitely many rational functions of the variables $x_{1}, x_{2}, \ldots, x_{n}$ is uniformly convergent for a specific area of these variables, if, after assuming an arbitrarily small quantity $\delta$, one can find the same finite number $n$ for all systems of values $x_{1}, x_{2}, \ldots, x_{n}$ from the given area, such that $\left|s-s_{n}\right|<\delta$. At the same time, this definition gives a justification of the word uniformly, [since] it should be possible to separate the same number of terms for all systems of values $x_{1}, x_{2}, \ldots, x_{n}$ from the given area, such that the error $\left[\left|s-s_{n}\right|, \mathrm{KV}\right]$ does not exceed a given limit $\delta$. First, one realizes that uniform convergence yields unconditional convergence. In fact, the concept of uniform convergence is more general. Therefore, in order to justify the assertion just made, we have yet to prove that uniform convergence also implies continuity (author's emphasis). ${ }^{51}$

\footnotetext{
49 For more on Heine's role for the subject of uniform convergence, see Viertel 2014, p. $157 \mathrm{ff}$.

50 BBAW, Nachlass Schwarz, No. 464, pp. 201-204.

51 BBAW, Nachlass Schwarz, No. 464, p. 201 f.: „Wir definieren diesen wichtigen Begriff folgendermaßen: die Summe von unendlich vielen rationalen Functionen der Variablen $x_{1}, x_{2}, \ldots, x_{n}$ ist für ein gewisses Gebiet derselben gleichmäßig convergent, wenn nach Annahme einer noch so kleinen Größe $\delta$ sich für alle Werthsysteme $x_{1}, x_{2}, \ldots, x_{n}$ die dem gegebenen Gebiete angehören, ein und dieselbe endliche Zahl $n$ angeben läßt, von der Beschaffenheit, daß $\left|s-s_{n}\right|<\delta$ ist. In dieser Definition ist gleichzeitig die Begründung des Wortes gleichmäßig enthalten, es soll eben möglich sein, für alle dem gegebenen Gebiete angehörigen Werthsystemen $x_{1}, x_{2}, \ldots, x_{n}$ eine gleiche Anzahl von Gliedern abzulösen, damit der Fehler eine gegebene Grenze $\delta$ nicht überschreite. Zunächst erkennt man, daß die gleichmäßige Convergenz die unbedingte Convergenz umfaßt. In der That ist der Begriff der gleichmäßigen Convergenz ein
} 
He claimed that uniform convergence implies unconditional (unbedingte) convergence (which is generally wrong) and added that the former is the more general concept of the two. I did not find any indications in other lecture notes that this could represent Weierstrass's conception of both notions of convergence. We find a second definition of uniform convergence in the section titled "Potenzreihen und die Criterien ihrer Convergenz":

If we assume the summation of infinitely many rational functions with several variables, we call the resulting series uniformly convergent, if, after assuming an arbitrarily small quantity $\delta$, one can find a number $n$ for all combinations of values $x_{1}, x_{2}, \ldots, x_{n}$ from a given domain of $2 n^{\text {th }}$ dimension, such that $\left|s-s_{n}\right|<\delta$ (author's emphasis). ${ }^{52}$

In both introductions, Weierstraß emphasized the independence of $n$ over all values of $x$-without an indication on the variable concerned, i.e., $\left.s_{n}(x)\right) .{ }^{53}$ This could not be found in earlier lecture notes. And we also see an increase in mathematical rigor due to a consistent use of symbolizations like $\delta$ as well as the sign of absolute value, but we also find Weierstraß picked up the Cauchy-influenced denotations $s, s_{n}$ for (partial) sums. These more general notations helped making the concept of uniform convergence applicable to products and, at some point, to sequences of functions. Its increasing integration into the subject matter can be seen in the theorems that are based on uniform convergence: We find the double series theorem (Nachlass Schwarz, No. 464 , p. 284), a theorem about the term by term differentiation of sums of infinitely many power series (p. 291), and a false statement about the uniform convergence of power series (p. 205):

So, $\sum_{n=0}^{n=\infty} a_{n} x^{n}$ is unconditionally convergent for all $x$, whose absolute value is smaller than the absolute value of $x_{0}$. But then the power series is also uniformly convergent in this range [...]. ${ }^{54}$

The last sentence is formulated imprecisely, since unconditional convergence does not imply uniform convergence for the same set of values. This statement could also be the result of Rudio misunderstanding Weierstraß.

Furthermore, we find an introduction of uniform convergence for infinite products, specifically for products of power series that was probably motivated by the double series theorem:

Footnote 51 continued

allgemeinerer. Wir haben daher, um die eben gemachte Behauptung zu rechtfertigen, noch nachzuweisen, daß die gleichmäßige Convergenz auch die Stetigkeit einschließt.“

52 BBAW, Nachlass Schwarz, No. 464, p. 208: „Denken wir eine unendliche Anzahl rationaler Functionen mit mehreren Veränderlichen summiert, so nennt man die dadurch entstehende Reihe gleichmäßig convergent, wenn nach Annahme einer beliebig kleinen Größe $\delta$ sich für alle Werthecombinationen $x_{1}, x_{2}, \ldots, x_{n}$ die einem gegebenen Gebiete $2 n$ ter Dimension angehören, eine Z $\overline{\mathrm{ahl} n}$ bestimmen läßt, so daß $\left|s-s_{n}\right|<\delta$. “ 53 In his criticism of Cauchy's famous 1821 theorem, Dirksen first introduced a refined notation for (infinite) series with an indication on the variable $x: S_{n}=f(x, n)$ (see Dirksen 1829). He was also the first to use a limit sign with indications on both the limit process and the variable (cf. Schubring 2005, pp. $471 \mathrm{ff}$.).

54 Nachlass Schwarz, No. 464, p. 205: „Es ist also $\sum_{n=0}^{n=\infty} a_{n} x^{n}$ unbedingt convergent für alle $x$, deren absoluter Betrag kleiner ist als der von $x_{0}$. Dann aber ist die Potenzreihe für diesen Bereich auch gleichmäßig convergent $[\ldots]$. “ 
Let us now examine under which condition an infinite product of power series represents an analytic function. Let $\varphi(x)=\prod_{\lambda} \varphi_{\lambda}(x)$. If we set $\varphi_{\lambda}=1+\psi_{\lambda}$, then $\prod_{\lambda}\left(1+\psi_{\lambda}\right)$ can be replaced by the series

$$
\mid \begin{aligned}
& 1 \\
& \psi_{0} \\
& \psi_{2}+\psi_{1} \psi_{2} \\
& \psi_{3}+\psi_{1} \psi_{3}+\psi_{2} \psi_{3}+\psi_{1} \psi_{2} \psi_{3} \\
& \ldots \ldots \ldots \ldots \ldots \ldots \ldots \ldots \ldots \ldots \ldots \ldots \ldots \ldots \ldots \ldots \ldots \ldots \ldots \ldots \ldots \ldots
\end{aligned}
$$

The uniform convergence of the product will then be defined by the uniform convergence of this series. The uniform convergence of the product is expressed by $p-p_{n}<\delta$ and this is also the condition of uniform convergence for the series that defines the infinite product. ${ }^{55}$

One sees the similarities to the definition of uniform convergence for infinite series on p. $201 \mathrm{f}$.: He chose the notations $p, p_{n}$ in dependence of Cauchy's original notations $s, s_{n}$ for infinite series and sums.

\subsubsection{Hurwitz's script}

Adolf Hurwitz, born in Hildesheim, Germany, shortly attended the University of Munich in 1877 before he went to Berlin for 1877-1878 to study under Kummer, Kronecker and Weierstraß. He returned to Munich in 1879 and followed his teacher Felix Klein to the University of Leipzig one year later. After his Habilitation in 1882 and further studies in Berlin in 1881-1882, he accepted an appointment as an extraordinary Professor at Königsberg in 1884. During the following years, David Hilbert and Hermann Minkowski became his students, and they both became good friends of Hurwitz. In 1892, Hurwitz was appointed to the Eidgenössisches Polytechnikum Zürich where he stayed until 1919.

During his first Berlin visit in 1877-1878, he attended Weierstrass's lecture on Theorie der analytischen Functionen. The following quotation from Hurwitz's script shows the introduction of uniform convergence, which can easily be converted to functions with several variables, as Weierstraß mentioned ${ }^{56}$ :

55 BBAW, Nachlass Schwarz, No. 464, p. 291 f.: ,Wir wollen nun noch untersuchen, unter welcher Bedingung ein unendliches Product von Potenzreihen eine analytische Function darstellt. Sei $\varphi(x)=\prod_{\lambda} \varphi_{\lambda}(x)$. Setzen wir $\varphi_{\lambda}=1+\psi_{\lambda}$ so wird $\prod_{\lambda}\left(1+\psi_{\lambda}\right)$ bekanntlich durch die Reihe

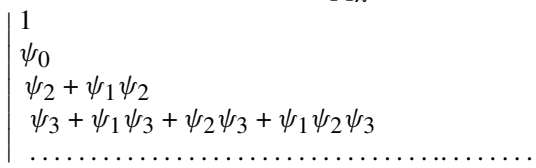

ersetzt. Die gleichmäßige Convergenz des Productes werden wir dann durch die gleichmäßige Convergenz dieser Reihe definieren. Denn die gleichmäßige Convergenz des Productes wird durch $p-p_{n}<\delta$ ausgedrückt, und dies ist auch die Bedingung der gleichmäßigen Convergenz für die das unendliche Product definierende Reihe."

56 " $[. .$.$] da alles, was im Folgenden gesagt wird, sich mit Leichtigkeit auf den allgemeineren Fall mehrerer$ Variablen übertragen läßt“", Weierstraß 1878, p. 59. 
[we assume] that the series $f_{1}(x), f_{2}(x), \cdots$ converges uniformly for all values of $x$, for which it has a sum at all. We know that if the series converges for $x=x_{0}$, a limit $v$ for $n$ can be determined such that for every $n>v$ $\left|s_{0}-\left(f_{1}\left(x_{0}\right)+f_{2}\left(x_{0}\right)+\cdots f_{n}\left(x_{0}\right)\right)\right|<\delta$ holds, where $s_{0}$ is the sum of the series for $x=x_{0}$ and $\delta$ denotes an arbitrarily small quantity. Now, if a limit $N$ can be set for $n$ such that for every $n>N\left|s-s_{n}\right|<\delta$ holds for all values of the variable included in the domain of validity of the series $f_{1}(x)+f_{2}(x)+\cdots$, then this latter series is called uniformly convergent. ${ }^{57}$

As we already saw in Rudio's script, Weierstraß uses a Cauchy-influenced notation for series and sums here. The term $s_{0}$, which denotes the value of $s$ for $x=x_{0}$ in the context of uniform convergence, only appears in the context of uniform convergence in this script. Obviously, this resembles Cauchy's notation $s$, but modified in order to indicate the variable, which may not be confused with the general meaning of $s_{n}$. It seems as if Weierstraß did not adopt a symbolic notation for a function represented by an infinite sum and with an indication on the variable. However, we find such a notation for a function represented by an infinite product, i.e., $\varphi(x)=\prod_{\lambda} \varphi_{\lambda}(x)$ (Nachlass Schwarz, No. 464, p. 291 f.). But most importantly, the above definition of uniform convergence represents one of the most rigorous, since, for the first time, it is required that the sum of the remainder should become $<\delta$ for all $n$ greater than $N=N(\delta)$. In both of Rudio's introductions of uniform convergence, it is only said that "one can find a number $n$."

As it was already pointed out, multiple scripts of one lecture course increase the reliability of what Weierstraß actually said when he lectured. In terms of Cauchyinfluenced notations, it is most likely that Weierstraß really referred to them in his 1878 course, since the inequality $\left|s-s_{n}\right|<\delta$ can be found in both Rudio's and Hurwitz's scripts. However, he simultaneously used the alternative notation $\left|s_{0}-\left(f_{1}\left(x_{0}\right)+f_{2}\left(x_{0}\right)+\cdots f_{n}\left(x_{0}\right)\right)\right|<\delta$ in Hurwitz's notes (Weierstraß 1878, pp. 59-60). Weierstraß gave another short explanation: "The condition can also be expressed as: $\mid f_{n+1}(x)+f_{n+2}(x)+\cdots$ in inf $\mid<\delta$ holds for a sufficiently large number $n$ and for each value of $x$ within the area of validity and convergence of the function." 58 Again, from today's point of view, it is not sufficient for uniform convergence to require $\mid f_{n+1}(x)+f_{n+2}(x)+\cdots$ in inf. $\mid<\delta$ for a sufficiently large $n$. Weierstraß, or the note-taker, did not seem to prioritize between the different definitions on pp. 59-60, although they differ in terms of mathematical rigor and content. One might conclude that the note-taker considered both definitions as equivalent or he did not pay much attention to the exactness of the verbal form. But then, the continu-

\footnotetext{
57 Weierstraß 1878, pp. 59 f.: ,,[wir setzen], daß die Reihe $f_{1}(x), f_{2}(x), \cdots$ für alle Werthe von $x$, für welche sie überhaupt eine Summe hat, "gleichmäßig convergiert". Wir wissen nämlich, daß, wenn die Reihe für $x=x_{0}$ convergiert, sich für $n$ eine Grenze $v$ so feststellen läßt, daß für jeden $n>v$ $\left|s_{0}-\left(f_{1}\left(x_{0}\right)+f_{2}\left(x_{0}\right)+\cdots f_{n}\left(x_{0}\right)\right)\right|<\delta$, wo $s_{0}$ die Summe der Reihe für $x=x_{0}$ und $\delta$ eine beliebig klein angenommene Größe bedeutet. Wenn nun eine Grenze $N$ für $n$ festgesetzt werden kann, so daß für jedes $n>N\left|s-s_{n}\right|<\delta$ wird für alle Werthe des Arguments, die in dem Gültigkeitsbereich der Reihe $f_{1}(x)+f_{2}(x)+\cdots$ liegen, so heißt diese letztere Reihe gleichmäßig convergent.“

58 Weierstraß 1878, p. 60: „Die Bedingung kann auch so ausgedrückt werden: $\mid f_{n+1}(x)+f_{n+2}(x)+\cdots$ in inf. $\mid<\delta$ für hinreichend großes $n$ und für jeden Werth von $x$ innerhalb des Gültigkeits- und Convergenzbereiches der Funktion.“
} 
ity theorem still holds when the sum of the remainder becomes arbitrarily small for a sufficiently large number $n=n(\delta)$. Nonetheless, these definitions are novelties in the cycle of lectures on analytic and elliptic functions and they show a further development of the concept of uniform convergence in terms of rigor.

In the section titled "Unendliche Summen und Produkte analytischer Funktionen", Weierstraß explained uniform convergence both for power series and analytic functions:

Here is something to be said about uniform convergence: A power series of $x$ or a series of infinitely many arithmetic expressions of $x$ is called uniformly convergent, if, for an arbitrarily small quantity $\delta$, a number $N$ can be determined such that for $n \geq N\left|s-s_{n}\right|<\delta$ holds for every value of $x$, for which the series has a finite value. 59

It is stated that if a power series is uniformly convergent, then this should hold for every value in the area of convergence. This seems to be a misunderstanding of the note-taker Hurwitz, since we only get uniform convergence in every closed and bounded subset of the disc of convergence. Weierstraß had already mentioned power series that converge only in a certain subset of their domain, e.g., here:

A series $P(x)$ defining an analytic function should be called uniformly convergent in the neighbourhood $\delta$ of $x_{0}$, if $P\left(x \mid x_{0}\right)$ is uniformly convergent for $\left|x-x_{0}\right|<\delta .^{60}$

For other theorems, we find the continuity theorem ("we now want to show that every function $\varphi(x)=f_{0}(x)+f_{1}(x)+\ldots$, which converges uniformly, changes continuously with its variable" 61 ) and a theorem stating that a series of analytic functions is again analytic (Weierstraß 1878, p. 113 f.).

Similar to Rudio's script, Weierstraß also dealt with infinite products of power series denoted as $\prod_{\lambda=0}^{\infty} \varphi_{\lambda}(x)$ and the requirements under which they represent analytic functions. These remarks on power series and their convergence are very similar to the respective passages in Rudio's script, as one would expect of two scripts of the same lecture course. Despite the similarities, uniform convergence of products is introduced slightly more rigorously here due to the use of symbolic notations and absolute value signs. Let $\sum \psi_{\lambda}$ be a uniform convergent sum of power series denoted as $\psi_{\lambda}$, and let $\left(1+\psi_{0}\right)\left(1+\psi_{1}\right)\left(1+\psi_{2}\right) \ldots$ be an infinite product that can also be written as $1+\psi_{0}+\psi_{1}+\psi_{0} \psi_{1}+\ldots$ Then, Weierstraß added:

We give the definition of uniform convergence of a product $p$ in such a way that $\left|p-p_{n}\right|<\delta$ should hold, if $\delta$ is an arbitrarily small quantity and $p_{n}$ is the

\footnotetext{
59 Weierstraß 1878, pp. 111 f.: „Hier soll etwas über die gleichmäßige Convergenz eingeschaltet werden. Eine Potenzreihe von $x$ oder eine Reihe von unendlich vielen Rechnungsausdrücken von $x$ heißt gleichmäßig convergent, wenn sich für ein beliebig klein angenommenes $\delta$ eine Zahl $N$ so bestimmen läßt, daß für $n \geq N$ $\left|s-s_{n}\right|<\delta$ für jeden Werth von $x$, für welche die Reihe einen endlichen Werth hat" (author's emphasises).

60 Weierstraß 1878, p. 113: „Eine eine analytische Funktion definierende Reihe $P(x)$ soll in der Umgebung $\delta$ von $x_{0}$ gleichmäßig convergent heißen, wenn für $\left|x-x_{0}\right|<\delta P\left(x \mid x_{0}\right)$ gleichmäßig convergent ist $[P$ $\left(x \mid x_{0}\right)$ represents a power series of $x$ centered at $\left.x_{0}\right] . "$

61 Weierstraß 1878, p. 60: „Wir wollen nun zeigen, daß jede Funktion $\varphi(x)=f_{0}(x)+f_{1}(x)+\cdots$, die gleichmäßig convergiert, sich stetig mit dem Argumente ändert.“
} 
product of the first $n$ terms of the infinite product. In fact, the number $n$ must be determined by $\delta$ such that $\left|p-p_{n}\right|<\delta$ holds for every value of the variable, for which $p$ has a value. ${ }^{62}$

In this explanation, uniform convergence for infinite products is stretched to the whole domain of convergence, which points to a mistake made by Hurwitz. The denotations $p, p_{n}$ have the same meaning as in Rudio's script, and it is claimed that $\left|p-p_{n}\right|<\delta$ holds for every value of $x$, while the number $n$ depends on the quantity $\delta$. As in Rudio's script, it remains unclear for how many numbers $n\left|p-p_{n}\right|<\delta$ should apply.

Hurwitz's and Rudio's introductions of uniform convergence of infinite products are clearly motivated by the double series theorem, and we will see a more original approach to convergent products in Kneser's script.

\subsection{Weierstrass's lectures and research between 1880 and 1886}

Weierstrass's state of health deteriorated over the years, so that he was forced to cancel all his lecture courses between 1883/1884-1885/1886 and in 1887/1888. Except for a few dates in January 1889 this was the end of his lectures at the University of Berlin (Biermann 1988, p. 140). This means that his lecture courses on analytic and elliptic functions from the early 1880 s are particularly interesting in revealing developments of the notion of uniform convergence.

\subsubsection{Adolf Kneser's script of a lecture on analytic functions}

Adolf Kneser studied mathematics in Heidelberg, Rostock and Berlin, where he also obtained his doctorate under Leopold Kronecker and Ernst E. Kummer in 1884. The certificate of matriculation from the archives of the University of Berlin reveals that he also attended Weierstrass's lectures and, particularly, the course on analytic functions (WS 1880/81). ${ }^{63}$ Weierstrass's introduction of uniform convergence is given as follows in Kneser's lecture notes:
A
series
converges
uniformly
within

a certain domain $B$ of $x$, if it is always possible, after assuming an arbitrarily small quantity $\varepsilon$, to separate a number of $n$ first terms such that the absolute value of the sum of the remainder always becomes $<\varepsilon$ for all $x$ within $B .^{64}$

\footnotetext{
62 Weierstraß 1878, p. 115 f.: „Die Definition der gleichmäßigen Convergenz eines Produktes $p$ stellen wir daher so, daß $\left|p-p_{n}\right|<\delta$ sein soll, wenn $\delta$ eine beliebig klein angenommene Größe ist, $p_{n}$ das Produkt der ersten $n$ Glieder des unendlichen Produktes, und zwar muß sich aus $\delta$ die Zahl $n$ so bestimmen lassen, $\mathrm{da} \beta\left|p-p_{n}\right|<\delta$ für jeden Werth der Variabeln ist, für welchen $p$ einen Werth hat."

63 I am grateful to Peter Ullrich (University of Koblenz and Landau, Germany), who informed me that Kneser`s Nachlass is preserved at the Göttingen State and University Library.

64 Göttingen State and University Library, Nachlass Adolf Kneser, Signatur Cod. Ms. A. Kneser B 3, p. 76: „Eine Reihe konvergiert innerhalb eines gewissen Bereiches $B$ der $x$ gleichförmig, wenn es nach Annahme eines beliebig kleinen $\varepsilon$ stets möglich ist, eine Anzahl von $n$ ersten Gliedern so abzusondern, daß der absolute Betrag des Restes stets $<\varepsilon$ ist, für alle $x$ innerhalb des Bereichs $B$ “ (author's emphasis).
} 


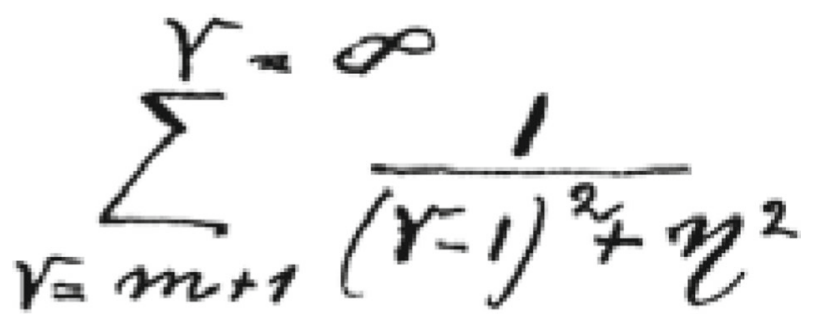

Fig. 4 Weierstrass's notation for an infinite series. Nachlass Schwarz, No. 470, p. 71

On the one hand, this is the first occurrence of the term gleichförmig (uniform) in the cycle of lectures. On the other hand, it is the first time that the domain where convergence applies is designated by a letter. Furthermore, this definition again shows that rigor and formalization did not continuously increase in his lecture courses: Weierstraß used a purely verbal formulation of the sum of the remainder instead of a symbolic notation (e.g., $\left|s-s_{n}\right|$ ) as introduced in Hurwitz's (SS 1878), Hettner's (SS 1874) and Pasch's notes (WS 1865/66). Even more, rigor and formalization were handled differently even in the same course, which is shown by the following alternative and more rigorous notation for the sum of the remainder: "From the assumption of the uniform convergence of $F(x)$ [which equals $\sum_{v=0}^{\infty} f_{v}(x)$; K.V.], it follows that $\left|\sum_{v=m}^{\infty} f_{v}(x)\right|<\delta$ holds for a certain number $n$, as soon as $m \geq n$." ${ }^{\prime 65}$ This definition is basically saying that $\left|s-s_{m-1}\right|<\delta$ should hold for (maybe) any number $m \geq n$, instead of just for $n$ as it was said in former lecture notes. Compared to previous notations such as $s-s_{n}, \sum \varphi(x)-\varphi_{1}(x)-\ldots-\varphi_{n}(x)$ (Pasch's script, WS 1865/1866), $\psi_{n+1}+\ldots+\psi_{n+m}$ (elliptic functions, WS 1870/1871), and $s_{0}-$ $\left(f_{1}\left(x_{0}\right)+f_{2}\left(x_{0}\right)+\cdots f_{n}\left(x_{0}\right)\right)$ (Hurwitz's script, SS 1878), this is another example of further refinements of the notation for uniform convergent series. Concerning the index-based sum notation used here, this was found earlier in the WS 1868/1869 script on elliptic functions (see Fig. 4). ${ }^{66}$

We find the following theorems using uniform convergence in Kneser's script:

- A continuity theorem, in which the continuity of the original functions in

\footnotetext{
65 Nachlass Adolf Kneser, Signatur Cod. Ms. A. Kneser B 3, p. 96: „Aus der vorausgesetzten gleichförmigen Konvergenz von $F(x)$ folgt, daß für ein bestimmtes $n\left|\sum_{v=m}^{\infty} f_{v}(x)\right|<\delta$ gemacht werden kann, sobald $m \geq n$." Note that it is not specified, for which values of $x$ the uniform convergence of $F(x)$ holds. 66 Originally, Weierstraß uses the series $\sum \frac{1}{(r-1)^{2}+\eta^{2}}$ with $r=1,2, \ldots, \infty$, to provide an upper bound for the second derivative of the power series $g(x)$, which appears in the initial equation $\frac{\sin (\pi x)}{x}=\prod^{\prime}\left(1-\frac{x}{n}\right) e^{\frac{x}{n}} C^{g(x)}$. The dash on the product sign $\prod$ commonly indicates that the index of multiplication runs through the natural numbers.
} 
the series is not explicitly claimed: "If a series converges uniformly within a certain domain, then its value changes continuously in this domain-the series is $\sum_{v=0}^{\infty} f_{v}$ $(x)=F(x)^{, " 67}$,

- a theorem stating that power series converge on the boundary of a specific disk: "Now let $F=\sum_{\lambda=0}^{\infty} A_{\lambda} x^{\lambda}$ be a power series convergent for all $|x|<r$; if $|\rho|<r$, the series converges uniformly for all $|x|=\rho$ ", 68

- a theorem on determining the product of two uniformly convergent power series, ${ }^{69}$ and

- a statement on the convergence of power series with several variables: "If the absolute values of all terms of a power series with several variables [designated as $\sum a_{\lambda \mu \nu \ldots} x^{\lambda} y^{\mu} z^{\nu} \ldots ; \mathrm{K} . \mathrm{V}$.] are below a certain positive quantity $g$ for $x=x_{0}$, $y=y_{0}, z=z_{0} \ldots$ which are all not equal to zero, then the series converges for every system of values that satisfies $|x|<\left|x_{0}\right|,|y|<\left|y_{0}\right| \ldots$. If we have any quantities $h<\left|x_{0}\right|, k<\left|y_{0}\right|, l<\left|z_{0}\right| \ldots$ and if we require $|x|<h,|y|<k$, $|z|<l \ldots$, then the series converges uniformly in the domain defined thereby."70

Kneser's script also shows a more formalized introduction of uniform convergence for infinite products compared to both Hurwitz's and Rudio's introductions. That is, infinite products are not solely introduced as representations of their respective series:

If the infinite product $F(x)=\prod_{v=0}^{\infty} f_{v}(x)$ has a finite value, then we have

$$
\prod_{v=n}^{\infty} f_{v}(x)=1+q_{n},
$$

in which $q_{n}$ becomes infinitely small for $n=\infty$. If we have $q_{n}<\varepsilon$ for all $x$ satisfying the condition $x-x_{0}<\delta$ as soon as $n$ has reached a certain value, given an arbitrarily small quantity $\varepsilon$, then one says that the product converges uniformly in the neighbourhood $\delta$ of $x_{0} .^{71}$

67 Nachlass Adolf Kneser, Signatur Cod. Ms. A. Kneser B 3, p. 76: „Konvergirt eine Reihe innerhalb eines gewissen Bereichs gleichförmig, so ändert sich ihr Werth in diesem Bereich stetig-die Reihe sei $\sum_{v=0}^{\infty} f_{v}$ $(x)=F(x) . “$

68 Nachlass Adolf Kneser, Signatur Cod. Ms. A. Kneser B 3, p. 92: "Es sei nun $F=\sum_{\lambda=0}^{\infty} A_{\lambda} x^{\lambda}$ eine für alle $|x|<r$ konvergente Potenzreihe; ist $|\rho|<r$, so konvergiert die Reihe für alle $|x|=\rho$ gleichmäßig."

69 Considering two power series $f_{0}(x)=\sum_{v=0}^{\infty} a_{v} x^{v}$ and $f_{1}(x)=\sum_{v=0}^{\infty} b_{v} x^{v}$ which are convergent for $|x|<r$ and uniformly convergent for $|x|<\rho<r$, then we can get the product $f_{0}(x) \cdot f_{1}(x)$ for all $|x|<\rho$ by multiplying them term by term (see Nachlass Adolf Kneser, Signatur Cod. Ms. A. Kneser B 3 , p. 100 f.).

70 Nachlass Adolf Kneser, Signatur Cod. Ms. A. Kneser B 3, p. 82: „Haben alle Glieder einer Potenzreihe mit mehreren Argumenten für die sämtlich von 0 verschiedene Werthe $x=x_{0}, y=y_{0}, z=z_{0} \ldots$ absolute Beträge, die alle unter einer bestimmten positiven Größe $g$ liegen, so konvergiert die Reihe für jedes Werthsystem, das der Bedingung $|x|<\left|x_{0}\right||y|<\left|y_{0}\right| \ldots$ genügt. Hat man im vorliegenden Falle beliebige Größen $h<\left|x_{0}\right| k<\left|y_{0}\right| l<\left|z_{0}\right| \ldots$ und setzt man voraus $|x|<h|y|<k|z|<l$... so konvergirt die Reihe in dem hierdurch definirten Bereich gleichförmig. “

71 Nachlass Adolf Kneser, Signatur Cod. Ms. A. Kneser B 3, p. 77 f.: „Hat das unendliche Produkt $F(x)=\prod_{v=0}^{\infty} f_{v}(x)$ einen endlichen Werth, so ist $\prod_{v=n}^{\infty} f_{v}(x)=1+q_{n}$ wo $q_{n}$ unendlich klein wird für $n=\infty$. Ist für alle $x$, welche der Bedingung $x-x_{0}<\delta$ genügen, $q_{n}<\varepsilon$, sobald $n$ eine bestimmte Größe erreicht hat, wo $\varepsilon$ eine beliebig klein vorgelegte Größe ist, so sagt man, das Produkt convergire gleichförmig in der Umgebung $\delta$ der Stelle $\left|x-x_{0}\right|$.“ 
Compared to 1878 , this introduction of a uniformly convergent product does not require its corresponding series. It also seems to be clearer to the reader that $q_{n}$ is required to become small for any number greater than or equal to a certain value.

\subsubsection{Georg Thieme's script of a lecture on analytic functions from WS 1882/1883}

The last lecture notes from the regular lecture courses of analytic and elliptic functions available are preserved in Schwarz's Nachlass and are titled "Einleitung in die Theorie der analytischen Functionen. Vorlesungen des Professor Dr. Weierstrass Berlin W. S. 1882-83." The name of the author on the front page reads "G. Thieme," but there was no student of Weierstraß named Thieme at this time. Hence he had bought these notes. Siegmund-Schultze (1988) points out that G. Thieme was Georg Thieme a professor at the college for mining engineers in St. Petersburg. ${ }^{72}$ Thieme also owned a transcription of a lecture course on Ausgewählte Kapitel aus der Funktionenlehre (1886). In Thieme's manuscript, uniform convergence is introduced as a sufficient condition for the continuity theorem. It is asked, "which conditions must be satisfied for $\sum f(x)$ to be a continuous function. So far, the proof could only be provided in the case that the series is uniformly convergent"73. For this purpose, he first recapped common convergence before explaining the property of uniform convergence for a sum of rational functions:

One has a series with a single variable. Let $x$ be a certain value of the same variable in the range of convergence [...]. One then knows that the absolute value of $S-S_{n}$ becomes smaller than an arbitrarily small quantity $\delta$ as soon as $n$ reaches or exceeds a certain limit $m$. This applies to every single value within the range of convergence. We now say that a sum of rational functions of $x$ converges uniformly within a certain domain, if, after assuming an arbitrarily small quantity $\delta$, it is possible to determine a number $n$ such that $\left|S-S_{n}\right|<\delta$ holds for all $x$ within the domain considered. ${ }^{74}$

The difference between uniform and pointwise convergence is clearly stressed here with the use of the formulation " $\left|S-S_{n}\right|<\delta$ holds for all $x$." In another introduction, the range of convergence is specified by the neighborhood of a fixed value:

Let $a$ be a certain value for which the series converges. We then say that the series converges uniformly in the neighbourhood of $a$, if a positive quantity $\delta$

\footnotetext{
72 In (Viertel 2014, p. 141), the purchase was mistakenly ascribed to Karl Gustav Thieme (*1852), who had studied in Breslau during 1873-7.

73 BBAW, Nachlass Schwarz, No. 465, p. 303: ,[...] welche Bedingungen müssen für $\sum f(x)$ erfüllt sein, damit es eine stetige Function sei. Der Beweis hat bis jetzt nur für den Fall geliefert werden können, daß die Reihe gleichförmig convergent ist" (author's emphasis).

74 BBAW, Nachlass Schwarz, No. 465, p. 304: „Man habe eine Reihe mit einer Veränderlichen. $x$ sei ein bestimmter Wert derselben im Convergenzbereich [...]. Man weiß dann, daß der absol. Betr. von $S-S_{n}$ kleiner wird als eine beliebig angenommen Größe $\delta$, so bald $n$ eine gewisse Grenze $m$ erreicht oder überschreitet. Dies gilt für jeden einzelnen Wert innerhalb des Convergenzbereiches. Wir sagen nun, eine Summe von Gliedern, die rationale Functionen von $x$ sind, convergieren innerhalb eines bestimmten Bereichs gleichförmig, wenn es nach Annahme einer beliebig kleinen Größe $\delta$ möglich ist, $n$ so zu bestimmen, daß $\left|S-S_{n}\right|<\delta$ ist für alle $x$, die innerhalb des betrachteten Bereiches liegen."
} 
can be determined such that for all $x$ satisfying the condition $|x-a| \leq \delta$, the series converges uniformly. ${ }^{75}$

And for infinite series, Weierstraß stated that uniform convergence in a neighborhood of a given value $a$ holds, if there exists a $\delta>0$ such that the series converges uniformly for all $|x-a| \leq \delta .^{76}$

Leaving a Cauchy-like notation for series behind (perhaps to avoid redundancy), Weierstraß introduced uniform convergence in the neighborhood of a fixed value also for functions of multiple variables with a particularly high level of mathematical rigor as compared to some earlier scripts:

We consider the [following] infinite series:

$$
F\left(x x_{1} x_{2} . . x_{\tau}\right)=\sum_{\gamma=0}^{\infty} f_{\gamma}\left(x x_{1}, . . x_{\tau}\right)
$$

Let $f$ be rational functions of the given variables. If one arbitrarily assumes a point $a a_{1}$. from the domain of the given variables, then it is said that the series converges uniformly in the neighbourhood of $a a_{1} .$. , if a quantity $\delta$ can be determined such that for every system $x x_{1}$.. satisfying the condition

$$
|x-a|<\delta,\left|x_{1}-a_{1}\right|<\delta, \ldots
$$

the absolute value of the difference between the sum of the series and the sum of the $n$ first terms is smaller than the arbitrarily small quantity $\varepsilon$, as soon as $n$ reaches or exceeds a certain limit $m .^{77}$

So, the concept is introduced here with a level of rigor comparable to Kneser's script, since we have $\left|s-s_{n}\right|<\varepsilon$ should hold for numbers $n$ which are $\geq m=m(\varepsilon)$.

\subsubsection{Weierstraß's supplementary lecture from 1886}

Because of Weierstraß's steadily declining state of health from the second half of the 1880 s, a regular continuation of his lecture courses was no longer possible and his retirement became imminent. Therefore, we close this overview with a discussion

\footnotetext{
75 BBAW, Nachlass Schwarz, No. 465, p. 306: „Es sei $a$ ein bestimmter Wert für den die Reihe convergiert. Wir sagen dann, die Reihe convergiert in der Nähe von $a$ gleichmäßig, wenn sich eine positive Größe $\delta$ so bestimmten läßt, daß für alle $x$, die der Bedingung $|x-a| \leq \delta$ genügen, die Reihe gleichmäßig convergiert.“

76 See BBAW, Nachlass Schwarz, No. 465, p. 306.

77 Nachlass Schwarz, No. 465, p. 310 f.: ,Wir betrachten die unendliche Reihe:

$F\left(x x_{1} x_{2} \ldots x_{\tau}\right)=\sum_{\gamma=0}^{\infty} f_{\gamma}\left(x x_{1}, \ldots x_{\tau}\right)$ die $f$ seien rationale Functionen der gegebenen Veränderlichen. Nimmt man in dem Bereich der Veränderlichen eine Stelle $a a_{1}$.. willkürlich an, so sagt man, die Reihe convergiere in der Nähe von $a a_{1}$.. gleichförmig, wenn sich eine Größe $\delta$ so bestimmen läßt, daß für alle Systeme $x x_{1} \ldots$, wo $|x-a|<\delta,\left|x_{1}-a_{1}\right|<\delta, \ldots$.

die Differenz zwischen der Summe der Reihe und der Summe der $n$ ersten Glieder dem absoluten Betrag nach kleiner als die beliebig klein angenommene Größe $\varepsilon$ ist, so bald $n$ eine gewisse Grenze $m$ erreicht oder überschreitet.“
} 
of a script from his final lecture course on the subject of analytic functions, entitled Ausgewählte Kapitel aus der Functionenlehre (1886).

Weierstraß planned this course as a singular follow-up to his lecture course on analytic functions (WS 1884/85), and it was held between the 25th of May and 3rd of August 1886. Unfortunately, the author of these notes remains unknown. ${ }^{78}$ Compared to other lecture notes discussed here, the 1886 script provides a first step toward a more general concept of uniform convergence, not only for infinite series (and products), but for sequences. It is introduced (quite uniquely) as "uniform approximation" and applied to a certain sequence $F(x, k)$ that converges to $f(x)$ for $k \rightarrow 0 .{ }^{79}$ He said

if we set two finite limits $a$ and $b$ for $x$, our theorem says that after assuming an arbitrarily small quantity $\varepsilon$, we can set an upper limit $\bar{k}$ for $k$ in such a way that for any given value of $x$ within the mentioned interval, we obtain $|F(x, k)-f(x)|<\varepsilon$. In this case, one says that the approximation is uniform for every value of $x$ within the finite interval $(a \ldots b) .{ }^{80}$

It is not specified whether the limits of the intervals noted as $(a \ldots b)$ are included or not, but the editor Siegmund-Schultze suggests interpreting them here (and in Weierstrass 1885) as closed intervals.

After Thomé's introduction of a preliminary stage of Weierstrass's M-test in 1866, we see Weierstraß himself referring to this important comparison test in this 1886 lecture course, again for functions with several variables: One says that $\sum_{\lambda=1}^{\infty} f_{\lambda}$ is uniformly convergent if there is a convergent series of positive values $\sum_{m=1}^{\infty} k_{m}$ such that $\left|f_{m}\right|<k_{m}$ holds for all $m$ larger than an assignable number (Weierstraß 1886a, p. 107).

\section{Conclusions}

\subsection{Different formulations of uniform convergence}

From the beginning of Weierstrass's lectures at the University of Berlin, we find the formulation im gleichen Grad (at the same rate) for his concept of uniform conver-

\footnotetext{
78 For an overview of the known transcriptions of this lecture course, see Siegmund-Schultze (1988, p. 14), and Viertel (2014, pp. 142 f.) for some comments on the modernization of notations.

79 The section is titled "Beweis des Satzes, daß $\lim _{k \rightarrow 0} F(x, k)=f(x)$, wenn $F(x, k)=\frac{1}{2 k \omega} \int_{-\infty}^{+\infty} f(u) \psi$ $\left(\frac{u-x}{k}\right) d u$ und $\omega=\int_{0}^{\infty} \varphi(u) d u$." Here, $f$ should be a well-defined, real and continuous function. Its absolute value should always be bounded. The function $\psi$ meets the same requirements as $f$. Additionally, it satisfies $\psi(x)=\psi(-x)$ and never changes its sign (cf. Weierstraß 1886a, pp. 25 ff.).

Note that the 1885 article already deals with the sequence $F(x, k)$ and its convergence, which indicates that it was his reference for respective parts of this lecture course.

80 Weierstraß 1886a, pp. 26: „Setzt man für $x$ zwei endliche Grenzen $a$ und $b$ fest, so sagt unser Satz, daß man nach Annahme einer beliebig kleinen Größe $\epsilon$ eine obere Grenze $\bar{k}$ für $k$ so festsetzen kann, daß für jeden beliebigen Wert von $x$ innerhalb des genannten Intervalls $|F(x, k)-f(x)|<\epsilon$ ist. Man sagt in diesem Falle, die Annäherung sei für jeden Wert von $x$ innerhalb des endlichen Intervalls $(a \ldots b)$ eine gleichförmige“" (author's emphasis).
} 
gence. This term was first used by his teacher Christoph Gudermann (1844) (and again in Reinhold Hoppe's 1865 textbook) in order to refer to the rate of convergence. Neither Gudermann nor Hoppe introduced a new concept with this term or, at least, they did not unfold it in their works. This indicates that both authors referred to the common concept of convergence.

It is widely believed today that Weierstraß adopted the notion of uniform convergence from Gudermann. But he just adopted the wording im gleichen Grad for a new concept of convergence he was going to develop throughout his lecture courses. It is also believed that Weierstraß had fully developed the concept of uniform convergence by 1841 , but the main point overlooked here is the later revision of the corresponding article. The introduction of uniform convergence and maybe the theorems stated by Weierstraß in the original paper from 1841 were clearly revised (see Sect. 2.2). However, he had referred to convergence at the same rate at least since his course on Differentialrechnung (1861; see Sect. 4) and he might have introduced the concept some years before.

In the lecture notes on analytic and elliptic functions, three different phrasings for uniform convergence were used, which are, in the order of their emergence, im gleichen Grade, gleichmäßig and gleichförmig (uniform). The term im gleichen Grade was the only formulation he used for uniform convergence until his 1870/71 course on elliptic functions. From a modern, more rigorous perspective, most of these definitions of im gleichen Grade describe the Cauchyan uniformity condition, which is, for the functions Weierstraß considered, equivalent to uniform convergence. The corresponding definitions found here can be summarized as follows: The sum $s_{n+m}-s_{n}$ (A) or $\left|s_{n+m}-s_{n}\right|$ (B) should become $<\delta$ for a certain number $n$ (1) or for every number $n \geq N=N(\delta)$ (2) and, in every definition found, for every number $m(m>0)$. We find different combinations of (A), (B) and (1), (2) as definitions of what is the Cauchyan uniformity condition. None of the note-takers and other authors mentioned a possible distinction between convergence in the sense of the uniform Cauchy condition and uniform convergence.

In the 1870/1871 course, Weierstrass first used the term gleichmässig for uniform convergence, which then appeared permanently until 1886. This formulation emerged simultaneously with new theorems about uniformly convergent series of functions with complex variables in the 1870/1871 script on elliptic functions. Its emergence also seems to correspond with the introduction of the absolute sign to the definition of uniform convergence. After then, the original term, im gleichen Grade, completely disappeared from both lecture cycles and so did the uniform Cauchy condition. The third formulation, gleichförmige Konvergenz, was used in 1880/1881-1886. As Richter emphasizes (1976, p. 159), these terms do not refer to different meanings of uniform convergence, although Siegmund-Schultze claimed that there are differences in terms of real and complex functions in Weierstrass's 1886-lecture (Siegmund-Schultze 1988, p. 18) by shortly referring to a paper by Medvedev (1974). ${ }^{81}$ From my understanding,

\footnotetext{
81 Actually, Medvedev does not analyze the 1886-lecture notes, but the article Zur Functionenlehre (1880). The author discussed Weierstraß's contribution to the proof that a convergent series of complex functions locally uniformly convergent on a compact set also converges uniformly on the entire set (Medvedev 1974, p. 89; Weierstraß 1880, pp. 203 f.). Concerning this paper, Richter came to a similar conclusion (1976, pp. 196 ff.). In any case, Medvedev did not discuss the issue of Siegmund-Schultze's claim.
} 
Weierstraß did not distinguish conceptually between the two terms gleichförmig and gleichmäßig.

The definitions of uniform convergence (excluding the Cauchyan uniformity condition) are basically of the following types: The remainder $s-s_{n}$ (A) or $\left|s-s_{n}\right|$ (B) should become $<\delta$ for a number $n=n(\delta)$ (1) or for every number $n \geq N=N(\delta)$ (2). Throughout the lecture notes, we find all combinations between (A), (B) and (1), (2). This shows that the development of the concept in terms of rigor did not steadily increase and, generally, introductions or short explanations of uniform convergence often varied between verbal forms and symbolic notations.

\subsection{Theorems on uniform convergence}

The first applications found in the lecture courses at the Gewerbeinstitut include the original questions that initially raised the awareness for new notions of convergence: We find the continuity theorem (the sum of infinitely many continuous functions is again continuous) here and in many lecture notes until 1882/1883. Also, with few exceptions, we find theorems about the permutability of summation and differentiation (or integration), which first occurred in the 1861 course at the Gewerbeinstitut and which were repeatedly introduced in other lecture notes until 1886. In the 1874 course, another recurrent theorem was added, which we now call the double series theorem of Weierstraß. It can also be found in both scripts of the 1878 course and, prominently, in the article Zur Theorie der Potenzreihen. Note that the continuity theorem as well as the theorem on permutability of summation and integration can still hold if $\left|s-s_{n}\right|<\delta$ is only satisfied for a number $n=n(\delta)$. This suggests that the definitions of (uniform) convergence were primarily customized for their application in certain theorems.

In terms of criteria for uniform convergence, we find the so-called Weierstraß $M$ test, which is first mentioned in his article Definition analytischer Functionen einer Veränderlichen vermittelst algebraischer Differentialgleichungen (Weierstraß 1842, p. 81). Since this paper was revised for a publication in 1894 , we cannot conclude whether he already referred to the M-test in the 1840s. A second reference can be found in Über die analytische Darstellbarkeit sogenannter willkürlicher Functionen einer Veränderlichen $(1885)^{82}$, which shows that the M-test was not new in 1885 since Weierstraß did not explicitly introduce it to the reader. According to Reinhold

\section{Footnote 81 continued}

Furthermore, Medvedev does not attribute the introduction of the very concept of uniform convergence to the two early papers of 1841 and 1842 (in their version of 1894) as so many other authors do. Instead, Weierstraß allegedly used the terminology "uniform convergence" only to refer to a result of Abel's lemma that allegedly yields uniform convergence of the series (Medvedev 1974, 78): A power series, converging in $x=a$, converges for all $|x|<a$. However, Abel did not intend to deal with uniform convergence (cf. Viertel 2014, pp. 42 ff.). Medvedev seems to use the lack of explicit definitions of uniform convergence in Weierstrass's 1894 papers to support his claim.

82 He showed that $\lim _{k \rightarrow 0} F(x, k)=\lim _{k \rightarrow 0} \frac{1}{2 k \omega} \int_{-\infty}^{+\infty} f(u) \psi\left(\frac{u-x}{k}\right) d u=f(x)$ converges uniformly and that $f$ $(x)$ can be locally represented by a rational function. In short, let $f(x)$ be a sum of infinitely many rational functions $f_{v}$ and let $\sum g_{v}$ be a convergent series of positive values. He found that $\left|f_{v}(x)\right| \leq g_{v}$ (Weierstrass 1885 , pp. 636 f.). Therefore, $f(x)=\sum_{v=0}^{\infty} f_{v}(x)$ converges unconditionally and uniformly in bounded intervals. 
Remmert (1984, 74), Weierstraß basically introduced the idea of this criterion in his article Zur Functionenlehre (1880):

This condition [of uniform convergence; K.V.] is certainly met if there is a series of certain positive quantities $g_{1}, g_{2}, g_{3}, \ldots$ for which we can state that for each point in the domain $B$ we have

$$
\left|f_{v}\right| \leq g_{v},(v=0, \ldots \infty)
$$

and the sum

$$
\sum_{v=0}^{\infty} g_{v}
$$

has a finite value. ${ }^{83}$

This introduction comes as a footnote, which suggests that Weierstraß had already referred to the $M$-test in earlier works. But, apart from the supplementary lecture held in 1886, it was not used in the other lecture notes discussed here. Thomé used a preliminary version of this criterion in 1866 and he probably learned about it in a script from Weierstraß.

How did Weierstraß himself reflect on the development and reception of uniform convergence? In his role as a co-founder of the concept of uniform convergence, he commented on the reception in France in a letter to H. A. Schwarz from 1881 as follows:

During the Easter holidays, I will publish a new revised and enlarged edition of my memoir on the unique functions, which I have been asked to do by many colleagues, including from France. In the case of the French, my last memoir has received more attention than it actually deserves [cf. Weierstraß 1876; K.V.]. It seems that the importance of the concept of uniform convergence has finally been understood. ${ }^{84}$

The level of reception in textbooks was reflected by Camille Jordan and the substantially reworked edition of his Cours d'analyse de l'École Polytechnique. In his Calcul différentiel, he utilized the concept of uniform convergence in order to develop the theorems on differentiation and integration of uniform convergent series that Weierstraß introduced in his lecture courses. He also referred to Weierstrass's example of a continuous but nowhere differentiable function (Jordan 1893, pp. 310 ff.). For a detailed

\footnotetext{
83 Weierstraß (1880, p. 202): Diese Bedingung ist sicher erfüllt, wenn es eine Reihe bestimmter positiver Grössen $g_{1}, g_{2}, g_{3}, \ldots$ giebt, für die sich feststellen lässt, dass an jeder Stelle des Bereichs $B$ $\left|f_{v}\right| \leq g_{v},(v=0, \ldots \infty)$ und die Summe $\sum_{v=0}^{\infty} g_{v}$, einen endlichen Werth hat.

84 BBAW, Nachlass Schwarz, No. 1175, Brief von Weierstraß an H. A. Schwarz vom 6. März 1881, pp. 124-5: ,In den Osterferien werde ich eine neue umgearbeitete und vermehrte Auflage meiner Abhandlung über die eindeutigen Funktionen veranstalten, wozu ich vielseitig, auch von Frankreich aus aufgefordert bin. Bei den Franzosen hat namentlich meine letzte Abhandlung mehr Aufsehen gemacht als sie eigentlich verdient. Man scheint endlich einzusehen, welche Bedeutung der Begriff der gleichmäßigen Konvergenz hat." This letter has already been mentioned and commented by Ludwig Bieberbach (1922).
} 
overview of contemporary developments and reception of Weierstrass's concept of uniform convergence, see Viertel (2014, chapter 7).

\section{Sources}

UNIVERSITÄTSBIBLIOTHEK BIELEFELD, SONDERAUFSTELLUNG QC

QC081+QC069 W418, Mitschrift der Vorlesung von K. Weierstraß: Ausgewählte Kapitel aus der Funktionenlehre. Unbekannter Autor. Sommer-Semester 1886, 1886.

ARCHIV DER BERLIN-BRANDENBURGISCHEN AKADEMIE DER WISSENSCHAFTEN, BERLIN [BBAW]

Nachlass H. A. Schwarz

453, G. Schmidt, Mitschrift der Vorlesung von K. Weierstraß: Differential- und Integralrechnung. 1859. 1 H., 35 B.

454, Theiler, Mitschrift der Vorlesung von K. Weierstraß (?): Differentialrechnung. 1868, 1869. 3 H. (Nr. II, III, IV). ${ }^{85}$

463 L. Kiepert, Mitschrift der Vorlesung von K. Weierstraß: Analytische Funktionen. 1868

464, F. Rudio, Mitschrift der Vorlesung von K. Weierstraß: Analytische Funktionen. 1878.

465, G. Thieme, Mitschrift der Vorlesung von K. Weierstraß: Analytische Funktionen. 1882/83.

466, Mitschrift der Vorlesung von K. Weierstraß: Analytische Funktionen. Ohne Datum, Schreiber unbekannt.

470, Mitschrift der Vorlesung von K. Weierstraß: Elliptische Funktionen. 1868/69. Schreiber unbekannt.

471, Mitschrift der Vorlesung von K. Weierstraß: Elliptische Funktionen. 1870. Schreiber unbekannt.

1175, Brief von Weierstraß an H. A. Schwarz vom 6. März 1881.

GÖTTINGEN STATE AND UNIVERSITY LIBRARY, HANS (HANDSCHRIFTEN, AutOGRAPHEN, NACHLÄSSE, SONDERBESTÄNDE)

Nachlass Adolf Kneser, Signatur Cod. Ms. A. Kneser B 3, K. Weierstrass, Adolf Kneser [Schreiber]: Vorlesungsnachschrift: Einleitung in die Theorie der analytischen Functionen. Berlin, WS 1880/81.-Ms.; 3, 97 Bl. (geh.)

\section{UNIVERSITY LIBRARY GIEßEN, SONDERSAMMLUNGEN}

Nachlass Moritz Pasch, Signatur I, 19: Nachschrift einer Weierstraß-Vorlesung v. Moritz Pasch. Berlin, 1865/66.

HumboldT-UNIVERSITÄT ZU BERLIN, UNIVERSITÄTSARCHIV, REKTOR \& SENAT

Gedruckte Vorlesungsverzeichnisse der philosophischen Fakultät von 1865 bis 1883.

85 It is unclear whether these notes come from one of Weierstrass's lectures. 


\title{
InSTITUT MitTAG-LEFFLER, SECTION LECTURE NoteS [IML]
}

\author{
H. A. Schwarz, Vorlesungsmitschrift von K. Weierstraß: Differentialrechnung. SS \\ 1861.
}

\section{UNIVERSITY LIBRARY BIELEFELD [UB]}

Signatur QA069 W418: Einleitung in die Theorieen der analytischen Functionen / von Prof. Dr. Weierstrass; nach den Vorlesungen im S.S. 1874 ausgearbeitet von G. Hettner. Handschriflich vervielfältigt.

Funding Open Access funding enabled and organized by Projekt DEAL.

Open Access This article is licensed under a Creative Commons Attribution 4.0 International License, which permits use, sharing, adaptation, distribution and reproduction in any medium or format, as long as you give appropriate credit to the original author(s) and the source, provide a link to the Creative Commons licence, and indicate if changes were made. The images or other third party material in this article are included in the article's Creative Commons licence, unless indicated otherwise in a credit line to the material. If material is not included in the article's Creative Commons licence and your intended use is not permitted by statutory regulation or exceeds the permitted use, you will need to obtain permission directly from the copyright holder. To view a copy of this licence, visit http://creativecommons.org/licenses/by/4.0/.

\section{References}

Bieberbach, Ludwig. 1922. Über den Briefwechsel von Weierstraß und H. A. Schwarz. Sitzungsberichte der Berliner Mathematischen Gesellschaft 21: 47-52.

Biermann, Kurt-Reinhard. 1988. Die Mathematik und ihre Dozenten an der Berliner Universität 1810-1933. Stationen auf dem Wege eines mathematischen Zentrums von Weltgeltung. Berlin: Akademie-Verlag.

Bölling, Reinhard. 1994. Karl Weierstrass - Stationen eines Lebens. Jahresbericht der Deutschen Mathematiker-Vereinigung 96 (2): 56-75.

Bölling, Reinhard. 2016. Zur Biographie von Karl Weierstraß und zu einigen Aspekten seiner Mathematik. In Karl Weierstraß (1815-1897), ed. Wolfgang König and Jürgen Sprekels, 53-121. Wiesbaden: Springer.

Bottazzini, Umberto (ed.) 1992. "Editor's Introduction”, A.-L. Cauchy Cours d'analyse de l'École Royale polytechnique. Première partie: analyse algébrique. [Nachdr. d. Ausg.] Paris, 1821. Bologna: Ed. CLUEB (Instrumenta rationis, 7).

Bottazzini, Umberto. 2016. Building analytic function theory: Weierstraß's approach in lecture courses and papers. In Karl Weierstraß (1815-1897), ed. Wolfgang König and Jürgen Sprekels, 165-194. Wiesbaden: Springer.

Cauchy, Augustin Louis. 1821. Cours d'Analyse de L'École Royale Polytechnique. Première Partie. Analyse algébrique.

Cauchy, Augustin Louis. 1853. Note sur les séries convergentes dont les divers termes sont des fonctions continues d'une variable reèlle ou imaginaire, entre des limites données. In: Oeuvres complètes d'Augustin Cauchy (1), 12, 1900, 30-36.

Dirksen, Enne Heeren. 1829. A. L. Cauchy's Lehrbuch der algebraischen Analysis. Aus dem Französischen übersetzt von C.L.B. Huzler, Königsberg 1828 (Rezension). Jahrbücher für wissenschaftliche Kritik 2: 211-222.

Dugac, Pierre. 2003. Histoire de l'analyse moderne. Autour de la notion de limite et de ses voisinages. Paris: Vuibert.

Gray, Jeremy. 2015. The real and the complex: A history of analysis in the 19th century, 1st ed., Springer undergraduate mathematics series Cham: Springer.

Gudermann, Christoph. 1844. Theorie der Modular-Functionen. Berlin: Reimer. (The first publication of this collected series of his articles was released in Crelle's Journal between 1838 and 1843).

Heine, Eduard. 1870. Ueber trigonometrische Reihen. Journal für die reine und angewandte Mathematik 71 (1869): 353-365. 
Holmboe, Berndt Michael. 1839. Oeuvres Complètes de N.H. Abel, Mathématicien: Avec Des Notes et Développements, vol. 2. Christiania: Chr Gröndahl.

Hoppe, Reinhold. 1865. Lehrbuch der Differentialrechnung und Reihentheorie mit strenger Begründung der Infinitesimalrechnung. Berlin: G. F. Otto Müller.

Jordan, Camille. 1893. Cours d'analyse de l'École Polytechnique: 1. Calcul différentiel, vol. 1, 2nd ed. Paris: Gauthier-Villars.

Killing, Wilhelm; Weierstrass, Karl. 1968. Einführung in die Theorie der analytischen Funktionen. Nach einer Vorlesungsmitschrift von Wilhelm Killing aus dem Jahr 1868. Münster (Schriftenreihe des Mathematischen Instituts der Universität Münster; Ser. 2, H. 38).

König, Wolfgang, and Jürgen Sprekels (eds.). 2016. Karl Weierstraß (1815-1897): Aspekte seines Lebens und Werkes - Aspects of his Life and Work. Springer Spektrum. Wiesbaden: Springer.

Maseres, Francis. 1777. A method of finding the value of an infinite series of decreasing quantities of a certain form, when it converges too slowly to be summed in the common way by the mere computation and addition or subtraction of some of its initial terms. Philosophical Transactions of the Royal Society of London 67: 187-230.

Medvedev, Fedor A. 1974. K istorii ponjatija ravnomernoj schodimosti rjadov. Istoriko-matematiceskie issledovanija 19 (1974): 75-93.

Nakane, Michiyo. 2014. Did Weierstrass's differential calculus have a limit- avoiding character? His definition of a limit in $\varepsilon-\delta$ style. BSHM Bulletin: Journal of the British Society for the History of Mathematics 29 (1): 51-59.

Pincherle, Salvatore. 1880. Saggio di una introduzione alle theoria delle funzioni analytiche secondo i principii di Prof. C. Weierstrass. Giornale di matematiche di Battaglini XVIII: 178-254.

Pringsheim, Alfred. 1899. Grundlagen der allgemeinen Funktionenlehre. In: Enzyklopaedie der mathematischen Wissenschaften mit Einschluss ihrer Anwendungen. Algebra, 2-1-1 (1899/1917). Leipzig: Teubner, 1-53.

Remmert, Reinhold. 1984. Funktionentheorie. Berlin: Springer.

Richter, Kurt. 1976. Zur Herausbildung, Entstehung und Entwicklung des Begriffs der gleichmäßigen Konvergenz: Ein Beitrag zur Geschichte der Mathematik des 19. Jahrhunderts. Dissertation. Halle: Pädagogische Hochschule.

Schubring, Gert. 2005. Conflicts between Generalization, Rigor, and Intuition: Number Concepts Underlying the Development of Analysis in 17th-19th Century France and Germany. New York: Springer.

Schubring, Gert. 2012. Lettres de mathématiciens français à Weierstraß-documents de sa réception en France. In: L'aventure de l'analyse, de Fermat à Borel. Mélanges en l'honneur de Christian Gilain, Éd. Suzanne Féry. Nancy: Presses Universitaires de Nancy, 567-594.

Schwarz, Hermann Amandus. 1873. Beispiel einer stetigen nicht differentiierbaren Function. In: Gesammelte mathematische Abhandlungen, herausgegeben von H. A. Schwarz, 2 (1890), 269-271. Berlin: Verlag von Julius Springer.

Seidel, Philipp Ludwig. 1847. Note über eine Eigenschaft der Reihen, welche discontinuirliche Functionen darstellen. Abhandlungen der Mathem.-Physikalische Classe der Königlich Bayerischen Akademie der Wissenschaften 5 (7): 381-394.

Siegmund-Schultze, Reinhard (ed.). 1988. Ausgewählte Kapitel aus der Funktionenlehre: Vorlesung, gehalten in Berlin 1886; mit der akademischen Antrittsrede, Berlin 1857, und drei weiteren Originalarbeiten von K. Weierstrass aus den Jahren 1870 bis 1880/86. Teubner-Archiv zur Mathematik 9, 1st ed. Leipzig: Teubner.

Stokes, George Gabriel. 1847. On the critical values of the sums of periodic series. Transactions of the Cambridge Philosophical Society 8: 533-583.

Thiele, Rüdiger. 2008. The Weierstrass-Schwarz Letters. In Kosmos Und Zahl. Beiträge Zur Mathematikund Astronomiegeschichte, zu Alexander von Humboldt Und Leibniz, ed. Hartmut Hecht, 395-410. Stuttgart: Steiner.

Thomae, Johannes. 1870. Abriß einer Theorie der Functionen einer complexen Veränderlichen und der Thetafunctionen einer Veränderlichen. Halle: L. Nebert.

Thomé, Ludwig Wilhelm. 1866. Ueber die Kettenbruchentwicklung der Gausschen Function $F(a, l, y, x)$. Journal für die reine und angewandte Mathematik 66: 322-336.

Viertel, Klaus. 2014. Geschichte der gleichmäßigen Konvergenz. Ursprünge und Entwicklungen des Begriffs in der Analysis des 19. Jahrhunderts. Wiesbaden: Springer.

Weierstraß, Karl. 1840. Über die Entwicklung der Modular-Functionen. In: Mathematische Werke I (1894), 1-49. Berlin: Mayer \& Müller. 
Weierstraß, Karl. 1841. Zur Theorie der Potenzreihen. In: Mathematische Werke I (1894), 67-74. Berlin: Mayer \& Müller.

Weierstraß, Karl. 1842. Definition analytischer Functionen einer Veränderlichen vermittelst algebraischer Differentialgleichungen. In: Mathematische Werke I (1894), 75-84. Berlin: Mayer \& Müller.

Weierstraß, Karl. 1843a. Bemerkungen über die analytischen Facultäten. In: Jahresbericht über das Königl. Progymnasium in Deutsch-Crone vom Herbst 1842 bis zum Herbst 1843, 3-17. Deutsch-Crone: P. Garms.

Weierstraß, Karl. 1843b. Bemerkungen über die analytischen Facultäten. In: Mathematische Werke I (1894), 87-103. Berlin: Mayer \& Müller.

Weierstraß, Karl. 1876. Zur Theorie der eindeutigen analytischen Functionen. Abhandlungen der Königlichen Akademie der Wissenschaften in Berlin 1876 (1877): 11-60.

Weierstraß, Karl. 1878. Einleitung in die Theorie der analytischen Funktionen. Vorlesung Berlin 1878 in einer Mitschrift von Adolf Hurwitz. Bearbeitet von Peter Ullrich. Dokumente zur Geschichte der Mathematik 4. Braunschweig [u.a.]: Vieweg.

Weierstraß, Karl. 1880. Zur Functionenlehre. In: Ausgewählte Kapitel aus der Funktionenlehre, Hrsg. Siegmund-Schultze, 1988, pp. 194-228. Leipzig: B. G. Teubner.

Weierstrass, Karl. 1885. Über die analytische Darstellbarkeit sogenannter willkürlicher Functionen einer Veränderlichen. In: Sitzungsberichte der Königlich Preußischen Akademie der Wissenschaften zu Berlin. 1885 (2): 633-639, 789-805.

Weierstraß, Karl. 1886a. Ausgewählte Kapitel aus der Funktionenlehre. Vorlesung, gehalten während des Sommersemesters 1886. In: Ausgewählte Kapitel aus der Funktionenlehre, Hrsg. Siegmund-Schultze, 1988, pp. 19-179. Leipzig: B. G. Teubner.

Weierstraß, Karl. 1886b. Zur Theorie der eindeutigen analytischen Functionen. In Abhandlungen aus der Functionenlehre, ed. Karl Weierstraß, 1-52. Berlin: Springer.

Weierstraß, Karl. 1894. Mathematische Werke, vol. 1. Berlin: Mayer \& Müller.

Weierstraß, Karl. 1895. Mathematische Werke, vol. 2. Berlin: Mayer \& Müller.

Weierstraß, Karl. 1915. Vorlesungen ueber die Theorie der elliptischen Funktionen von Karl Weierstrass, bearbeitet von J. Knoblauch. Hildesheim: Olms [u.a.].

Publisher's Note Springer Nature remains neutral with regard to jurisdictional claims in published maps and institutional affiliations. 